\title{
Effects of Medicare Payment Reform: Evidence from the Home Health Interim and Prospective Payment Systems
}

\section{Citation}

Huckfeldt, Peter J., Neeraj Sood, José J Escarce, David C. Grabowski, and Joseph P. Newhouse. 2012. Effects of Medicare Payment Reform: Evidence from the Home Health Interim and Prospective Payment Systems. HKS Faculty Research Working Paper Series RWP12-007, John F. Kennedy School of Government, Harvard University.

\section{Published Version}

http://web.hks.harvard.edu/publications/workingpapers/citation.aspx?Publd=8245

\section{Permanent link}

http://nrs.harvard.edu/urn-3:HUL.InstRepos:8506865

\section{Terms of Use}

This article was downloaded from Harvard University's DASH repository, and is made available under the terms and conditions applicable to Other Posted Material, as set forth at http:// nrs.harvard.edu/urn-3:HUL.InstRepos:dash.current.terms-of-use\#LAA

\section{Share Your Story}

The Harvard community has made this article openly available.

Please share how this access benefits you. Submit a story.

Accessibility 


\section{Effects of Medicare Payment Reform: Evidence from the Home Health I nterim and Prospective Payment Systems Faculty Research Working Paper Series}

\section{Peter J. Huckfeldt}

RAND Corporation

Neeraj Sood

USC School of Pharmacy and NBER

\section{José J. Escarce}

UCLA Med-GIM-HSR and NBER

David C. Grabowski

Harvard University

\section{Joseph P. Newhouse}

Harvard University and NBER

\section{March 2012 \\ RWP12-007}

\footnotetext{
The views expressed in the HKS Faculty Research Working Paper Series are those of the author(s) and do not necessarily reflect those of the John F. Kennedy School of Government or of Harvard University. Faculty Research Working Papers have not undergone formal review and approval. Such papers are included in this series to elicit feedback and to encourage debate on important public policy challenges. Copyright belongs to the author(s). Papers may be downloaded for personal use only.
} 
EFFECTS OF MEDICARE PAYMENT REFORM:

EVIDENCE FROM THE HOME HEALTH INTERIM AND PROSPECTIVE PAYMENT SYSTEMS

\author{
Peter J. Huckfeldt \\ Neeraj Sood \\ José J Escarce \\ David C. Grabowski \\ Joseph P. Newhouse \\ Working Paper 17870 \\ http://www.nber.org/papers/w17870 \\ NATIONAL BUREAU OF ECONOMIC RESEARCH \\ 1050 Massachusetts Avenue \\ Cambridge, MA 02138 \\ February 2012
}

The authors wish to acknowledge the role of Melinda Beeuwkes Buntin at the outset of this project. This study was funded in part by National Institute of Aging (NIA) Grant R01-AG031260 and a grant (No. R01-HS018541) from the Agency for Healthcare Research and Quality. The authors thank Mark Totten for his excellent programming support. The views expressed herein are those of the authors and do not necessarily reflect the views of the National Bureau of Economic Research.

At least one co-author has disclosed a financial relationship of potential relevance for this research. Further information is available online at http://www.nber.org/papers/w17870.ack

NBER working papers are circulated for discussion and comment purposes. They have not been peerreviewed or been subject to the review by the NBER Board of Directors that accompanies official NBER publications.

(C) 2012 by Peter J. Huckfeldt, Neeraj Sood, José J Escarce, David C. Grabowski, and Joseph P. Newhouse. All rights reserved. Short sections of text, not to exceed two paragraphs, may be quoted without explicit permission provided that full credit, including $\odot$ notice, is given to the source. 
Effects of Medicare Payment Reform: Evidence from the Home Health Interim and Prospective Payment Systems

Peter J. Huckfeldt, Neeraj Sood, José J Escarce, David C. Grabowski, and Joseph P. Newhouse NBER Working Paper No. 17870

February 2012

JEL No. H42,I1

\section{ABSTRACT}

Medicare continues to implement payment reforms that shift reimbursement from fee-for-service towards episode-based payment, affecting average and marginal reimbursement. We contrast the effects of two reforms for home health agencies. The Home Health Interim Payment System in 1997 lowered both types of reimbursement; our conceptual model predicts a decline in the likelihood of use and costs, both of which we find. The Home Health Prospective Payment System in 2000 raised average but lowered marginal reimbursement with theoretically ambiguous effects; we find a modest increase in use and costs. We find little substantive effect of either policy on readmissions or mortality.

Peter J. Huckfeldt

RAND Corporation

Santa Monica, California

Peter_Huckfeldt@rand.org

Neeraj Sood

Department of Clinical Pharmacy

USC School of Pharmacy

1985 Zonal Avenue

Los Angeles, CA 90033

and NBER

nsood@usc.edu

José J Escarce

UCLA Med-GIM-HSR

911 Broxton Avenue

Box 951736

Los Angeles, CA 90024

and NBER

jescarce@mednet.ucla.edu
David C. Grabowski

Harvard University

Department of Health Care Policy

Harvard Medical School

180 Longwood Avenue

Boston, MA 02115

grabowski@med.harvard.edu

Joseph P. Newhouse

Division of Health Policy Research and Education

Harvard University

180 Longwood Avenue

Boston, MA 02115-5899

and NBER

newhouse@hcp.med.harvard.edu 


\section{Introduction}

With the passage of the Patient Protection and Affordable Care Act (ACA), policymakers face the challenge of minimizing health care costs while maintaining or improving quality of care. One prominent approach shifts provider reimbursement from fee-for-service to episode-based payments to improve efficiency and accountability. For example, the Center for Medicaid and Medicare Services is currently piloting programs that provide a fixed payment for an acute hospital stay and any subsequent post-acute care (CMS 2011). However, these reforms require an appropriate definition of a treatment "episode" and understanding the effects of alternate reimbursement rules.

How can prior experience with payment change inform the current efforts to reform Medicare reimbursement? The Medicare home health benefit has transitioned through multiple reimbursement regimes and thus provides an excellent laboratory to study the influence of marginal and average reimbursement changes on home health admissions, provider costs, and Medicare costs.

In 1983, in an attempt to curtail rapidly increasing inpatient hospital costs, Medicare instituted the Inpatient Prospective Payment System, which provides a single payment for the inpatient stay, based on principal diagnosis, complications and comorbidities, procedure use, and local wages. However, post-acute services including home health care were still reimbursed on a cost basis subject to upper limits. As a result, admissions, patient visits, and resource use skyrocketed in home health agencies, resulting in Medicare home health expenditures increasing from \$2 billion in 1987 to \$17 billion in 1997 (MedPAC 2002).

In the Balanced Budget Act of 1997 (BBA 1997), Congress responded to spiraling post-acute care use by mandating prospective payment systems for postacute care. Because a workable system for home health agencies was not available, the Congress mandated the almost immediate adoption of an "Interim 
Payment System" (IPS) in October 1997. The IPS imposed substantially lower limits on Medicare reimbursement to home health agencies. It reduced average payments per visit and effectively eliminated marginal reimbursement past the limits. Subsequently, Medicare devised a home health agency prospective payment system (PPS) that provided reimbursement for each 60-day home health episode as a function of patients' clinical status, functional status, and service use (MedPAC 2010a). The PPS, implemented in October 2000, increased average payments to home health agencies, but, by some metrics, marginal reimbursement within a 60-day home health episode was further reduced ${ }^{1}$.

A number of papers examine the impacts of the Home Health IPS and PPS on payments, costs, and patient outcomes. Previous research has shown that the IPS reduced both the probability of using home health and the number of visits per patient (McCall et al. 2001, 2003b, McKnight 2006, MedPAC 2010a). This decrease in utilization was concentrated in less healthy Medicare patients but had little to no effect on adverse health outcomes (McKnight 2006). Additionally, over 30 percent of home health agencies exited after the IPS (MedPAC 2010b). Exiting facilities had a higher intensity of visits per patient, while newer and smaller providers in more competitive markets were able to expand their market share (Porel et al. 2006). Research on the PPS is more limited, but finds a greater use of therapy relative to home health aide visits, with little overall effect on patient outcomes or quality of care (Schlenker et al. 2005, MedPAC 2010b).

In this paper, we contribute to the previous literature by contrasting the Home Health IPS and PPS in a single unified framework, contrasting their differing effects on marginal and average reimbursement. We describe a conceptual framework that models home health agencies' admission and treatment policies as a function of Medicare reimbursement policy and provides

\footnotetext{
1 There are outlier payments for exceptionally costly patients, per visit payments for "short stay" outliers, and until 2008 agencies received additional payment for providing 10 or more rehabilitation visits.
} 
separate predictions for the IPS and the PPS. We develop an empirical strategy that simulates changes in admissions and resource use after each policy shift for a constant cohort of patients, thereby controlling for patient selection or changes in the composition of patients over time. Additionally, we estimate admission and treatment functions for a single cohort of patients, and use the estimates to simulate admission probabilities and resource use for successive patient cohorts to isolate selection effects. We also investigate the impacts of each policy on patient outcomes including mortality and hospital readmission. Finally, we estimate heterogeneous effects on admissions and costs based on differential changes in Medicare payments to further gauge the relative importance of average and marginal reimbursement. Throughout our empirical analysis, we use a rich dataset comprised of 100 percent Medicare acute and post-acute claims, denominator files, and provider data over the period 1996 through 2002.

Our conceptual model predicts that home health agencies' admissions and resource use will decrease with the IPS, but shows that the PPS has ambiguous effects due to offsetting changes in marginal and average reimbursement. Our estimates confirm that the IPS substantially decreased Medicare payments. We show that this decline in average and marginal reimbursement led to a sharp decline in home health admissions and resource use conditional on admission. In contrast, while the PPS increased average payments to providers above pre-IPS levels (in nominal terms), admissions and resource use conditional on admission increased only marginally. In both cases, we find little evidence of an effect on mortality or readmissions. We find heterogeneous effects on costs that vary with differential changes in average payments. Overall our results suggest that providers are responsive to both marginal and average reimbursement in determining treatment intensity and admissions, however changes in resource use and admissions induced by these payment changes had little impact on the patient health outcomes. 
The paper proceeds as follows. Section 2 provides background on home health agencies and changes in reimbursement policy. Section 3 discusses our conceptual framework. Section 4 describes the data, section 5 discusses the empirical strategy, section 6 describes the results, and section 7 concludes.

\section{The Home Health IPS and PPS}

Home health agencies provide skilled nursing, physical therapy, nurse aide, and medical social work services to Medicare beneficiaries who are unable to leave their homes without difficulty. In 2008, 3.2 million fee-for-service patients received the home-health benefit, resulting in $\$ 17$ billion in Medicare home health expenditures (MedPAC 2010b).

In 1983, the Medicare inpatient prospective payment system was implemented, providing a single payment to providers for an acute care episode as a function of patients' principal diagnosis, procedures used, complications and comorbidities, and adjustments based on local labor market conditions. At the same time, Medicare home health reimbursement was still cost-based (as were other post-acute settings), with limits based on the lower of an average cost per visit or total "reasonable costs" (Grimaldi 2002). Acute care length-of-stay steadily decreased in the years immediately following the acute PPS, with little immediate change in post-acute use. Court decisions in the late 1980s, however, held certain regulations governing eligibility for post-acute services to be illegal. Subsequently acute providers "unbundled" the marginal day from the acute inpatient episode and moved it to a post-acute setting, thereby receiving marginal reimbursement from Medicare. Indeed, the early 1990s saw explosive growth in hospital-based post-acute units and post-acute care use more generally (Newhouse 2002). Between 1987 and 1997, the number of Medicare patients using home health services doubled, the number of visits per patient increased from 23 to 78 , 
and, as mentioned above, Medicare spending on home health services grew from $\$ 2$ billion to $\$ 17$ billion (Grimaldi 2002, MedPAC 2002).

Congress and Medicare responded to ballooning post-acute expenditures by mandating prospective payment systems for all types of post-acute care in the Balanced Budget Act of 1997, but also immediately imposed the Home Health Interim Payment System (IPS). For home health agencies that had entered the market after 1994 the IPS imposed a per-patient cap on visits equal to national median per-patient costs. For older facilities, the limit was a weighted average of census division per-patient costs (25\%) and agency specific per-patient costs (75\%) in 1994 (McKnight 2006). Additionally, services previously contracted out were subject to these limits (Grimaldi 2002). Finally, the IPS also targeted fraudulent practices by home health providers.

The Home Health IPS was meant to be a temporary measure to contain home health costs, and, as called for in the law, a prospective payment system for home health was implemented October 1, 2000. The Home Health PPS provided prospective rates for a 60-day episode based on patients' home health resource group. The home health resource group was defined by clinical, functional, and service utilization attributes, based on nurse assessments (Grimaldi 2002).

Figure 1 shows average Medicare reimbursement per-home health patient separately for patients discharged from the hospital with a primary diagnosis of stroke, hip fracture, and joint replacement. The first vertical line indicates the quarter prior to the Home Health IPS and the second vertical line indicates the quarter prior to the Home Health PPS. This figure shows that the IPS considerably decreased average Medicare reimbursement for home health patients, while the PPS increased average reimbursement to above pre-IPS levels (in nominal terms). Marginal reimbursement, however, was further reduced under the PPS. The independent trajectories of average and marginal payments 
under the IPS and PPS allow us to investigate the separate effects of marginal versus average reimbursement on admissions and resource use.

\section{Conceptual Framework}

In this paper, we are interested in providers' decisions to admit patients and the level of treatment given to patients conditional on admission as a function of both average and marginal reimbursement. We use a conceptual model, developed by Sood et al. (2011), drawing on previous models by Hodgkin and McGuire (1994) and Ellis and McGuire (1996). Hodgkin and McGuire model providers' treatment policy as a function of marginal and average payments, where providers increase treatment intensity to attract new patients when they become more profitable. Ellis and McGuire explicitly model providers' admission and treatment policies as a function of reimbursement, although they do not distinguish between average or marginal reimbursement changes. In contrast, we explicitly model providers' admissions and treatment policies as a function of both marginal and average reimbursement.

Consider a non-profit home health agency that has to choose between $j=1 \ldots N$ patients to admit for home health services. The provider chooses an admissions policy that determines the probability of admitting patient $j(p)$ and a treatment policy that determines treatment intensity $(c)$ for patient $j$, as a function of a fixed payment per patient $(a)$ and marginal reimbursement $(m)$ for additional services.

The provider maximizes the utility function, as in (1):

$$
\max _{w r t p, c} U\left(E(\pi), p_{j}, c_{j}\right)
$$

with expected profits as in (2),

$$
E(\pi)=\sum_{j=1}^{N} p_{j}\left(a_{j}+\left(m_{j}-1\right) c_{j}\right)
$$

The first order condition for the admissions decision is given in (3): 


$$
\left[p_{j}\right]: U_{p_{j}}=-U_{\pi}\left(a_{j}+\left(m_{j}-1\right) c_{j}\right)
$$

Equation (3) implies that providers choose an admission policy such that the marginal utility of an increase in admission probability for a patient $j$ equals the change in profits from admitting the patient times the marginal utility of profits. Equation (3) also implies that any patient $j$ that is profitable (taking $c$ as fixed) will be admitted, assuming no capacity constraints. Any reduction in marginal reimbursement $(m)$ or the fixed payment $(a)$ will decrease the profitability of patient $j$ and lower $j$ 's probability of home health admission. This condition predicts that the Home Health IPS, characterized by a reduction in both $a$ and $m$, would reduce admissions.

A for-profit agency is assumed to take all patients for whom $E(\pi)$ is positive if there are no capacity constraints. If there are such constraints, the provider takes the most profitable patients until the constraint is binding. Like the nonprofit case, decreases in $a$ or $m$ will render some marginal patients unprofitable.

The Home Health PPS, however, was characterized by an increase in a fixed payment per 60-day episode, which increased average reimbursement, and a decrease in marginal reimbursement (for 5 or more visits in an episode $m=0$ ). Thus, the model offers ambiguous general predictions on the impact of the PPS on patient volume.

Equation (4) shows the first order condition determining the nonprofit provider's treatment. We assume that an increase in $c$ attracts more patients and that the added patients are drawn at random from the same distribution as existing patients.

$$
\left[c_{j}\right]: U_{c}=-U_{\pi}\left(1-m_{j}-E(\pi)^{\partial N} / \partial c\right)
$$

This condition implies that providers choose intensity for patient $j$ such that the marginal utility of intensity is equal to the change in profits times the marginal 
utility of profits. Profits change for two reasons. First, increasing intensity reduces profits as long as marginal reimbursement is less than one. Second, increasing intensity increases profits due to an increase in demand or admissions as long as the marginal patient is profitable. A for-profit agency will choose $c$ to attract profitable patients subject to a capacity constraint (or a population constraint on profitable patients). Equation (4) shows that marginal reimbursement and treatment intensity are positively related. An increase in average reimbursement increases profits, decreasing the marginal utility of profits; as a result, average reimbursement and treatment intensity are also positively related. Any competition from other post-acute providers strengthens this relationship. Thus, this condition predicts that the IPS would lead to lower treatment intensity, as marginal and average reimbursement decreased. Again, this condition offers ambiguous predictions for the PPS. The increase in average reimbursement offsets the decrease in marginal reimbursement, leading to ambiguous effects on treatment intensity.

\section{Data}

We use two separate samples of patients for analyses of the Home Health IPS and PPS. The sample for the IPS includes patients discharged from acute care between January 1996 and June 1999. The IPS was implemented in October 1997, so this provides seven quarters of discharges before and after the IPS. The sample for the PPS includes patients discharged from acute care between January 1999 and June 2002. The PPS was implemented in October 2000, so this again provides seven quarters of acute discharges before and after the PPS. 
The sample consists of patients whose principal diagnosis at acute admission was stroke, lower extremity joint replacement, or hip fracture ${ }^{2}$. The units of analysis are individual acute discharges, where outcomes are measured over the initial acute stay plus a fixed episode period following the acute discharge. Our main analysis uses a post-acute episode length of 90 days; thus, any acute admission occurring during the 90 days following the acute discharge is labeled an acute readmission. ${ }^{3}$ We link a number of data sources to construct the covariates and outcomes variables used in our analysis. In this section we describe the construction of the measures used in the analysis.

\section{a. Medicare Payment and Costs}

We use the Medicare FFS claims data linked to data from Medicare cost reports to construct the key payment (i.e. Medicare reimbursement) and cost measures. The Medicare claims data include 100 percent Medicare standard analytic files (SAF) for home health agency claims linked with 100 percent MEDPAR data for acute hospital, inpatient rehabilitation facility, and long term care hospital claims from January 1996 to June 2002. We define home health reimbursement for each observation as total Medicare payments to home health agencies occurring within a 90-day post-acute episode following an initial acute care discharge. To measure costs, we multiply the number of visits during a 90day post-acute episode by a facility's cost per visit (for a given calendar year) obtained from Medicare cost reports.

\footnotetext{
2 Stroke patients are defined as those with a principal diagnosis in the acute hospital stay of intracerebral hemorrhage (diagnosis code 431.xx), occlusion and stenosis of precerebral arteries with infarction (433.x1), occlusion of cerebral arteries with infarction (434.x1), or acute but ill-defined cerebrovascular disease (436.xx). Hip fracture patients are defined as patients with a primary diagnosis of fractures of the neck or the femur (820.xx). Lower extremity joint replacement patients were defined as patients with a primary diagnosis for joint replacement, excluding hip fracture patients and patients with reattachment procedures.

3 Longer post-acute episodes may capture later unrelated readmissions and subsequent costs, whereas shorter episodes may miss related costs, readmissions, and patient outcome. In analyses not reported, we examine the sensitivity of the results to differing post-acute episode lengths and find similar results.
} 


\section{b. Patient Characteristics}

We use information from the acute claims files and enrollment files to measure patient characteristics. For each patient, we collect (and control for) the list of comorbidities developed by Elixhauser et al. (1998) ${ }^{4}$. We use information from Medicare enrollment files to describe patient demographics including gender, age (indicators for five-year bands), race, and whether the patient lives in a MSA, adjacent to a MSA, or in a rural area. We also control for whether patients are dual eligibles (i.e. receive Medicaid due to low-income).

\section{c. Health Outcomes}

Our primary health outcome is mortality at the end of a 90-day episode, measured from the Medicare denominator or enrollment file. We also measure readmissions to acute care within the 90-day post-acute episode using the claims data.

\section{d. Provider characteristics}

Our analysis also controls for the characteristics of discharging acute providers (i.e., hospitals), as these may influence post-acute care. We derive information on the Medicare percentage of patient days in the previous year from providers' cost reports to CMS. We use the Medicare Provider of Services file (a provider level database maintained by CMS) to determine the ownership status of a particular facility (government, non-profit, or for profit) and the size of a facility (average daily census and number of beds). We use information from the Acute Impact file on average daily census, teaching status (acute resident to average daily census ratio), and low-income (Disproportionate Share-DSH) patient percentage as additional controls.

\footnotetext{
${ }^{4}$ Comorbidities include AIDS, alcoholism, deficiency anemias, rheumatoid arthritis/ collagen vascular diseases, blood loss anemia, congestive heart failure, chronic pulmonary disease, coagulopathy, depression, diabetes with chronic complications, diabetes without chronic complications, drug abuse, hypothyroidism, liver disease, lymphoma, fluid and electrolyte disorders, metastatic cancer, other neurologic disorders, obesity, paralysis, peripheral vascular disease, psychoses, pulmonary circulation disease, renal failure, solid tumor without metastasis, peptic ulcer disease excluding bleeding, valvular disease, and weight loss.
} 
Our IPS base sample consists of 980,905, 727,941, and 864,664 episodes of care for stroke, hip fracture, and joint replacement. We dropped one percent of stroke episodes, two percent of hip fracture episodes, and one percent of joint replacement episodes due to missing cost information and other missing data. Our PPS base sample includes 908,706, 702,137, and 948,938 episodes of care for stroke, hip fracture, and joint replacement. We dropped one percent of observations for each condition due to missing data. Summary statistics spanning the entire sample period (from 1996 q1 through 2002 q2) are displayed in Table 1.

\section{Empirical Approach}

Within a home health agency unconditional costs (i.e., across all acute discharges whether or not admitted to an home health agency) can change after a reimbursement change either because of changes in the probability of being admitted $(p)$ or changes in costs conditional on being admitted (c). In addition, the probability of being admitted and conditional costs are both functions of individual characteristics $(x)$.

After payment reform, changes in admission probabilities originate from the admission policies of home health agencies for a given patient (the shift from $p^{\text {pre }}$ to $p^{\text {post }}$ in equation 7) and from changes in the composition of individuals discharged from acute care hospitals (the shift from $x^{\text {pre }}$ to $x^{\text {post }}$ in equation 7$)^{5}$.

$$
\Delta p_{\text {hha }}=p_{\text {hha }}^{\text {post }}\left(x^{\text {post }}\right)-p_{\text {hha }}^{\text {pre }}\left(x^{\text {pre }}\right)
$$

The goal of our empirical strategy is to disentangle admission policy changes from shifts in the composition of acute discharges. Equation (7) can be rewritten as in (8):

$\Delta p_{\text {hha }}=\left[p_{\text {hha }}^{\text {post }}\left(x^{\text {pre }}\right)-p_{\text {hha }}^{\text {pre }}\left(x^{\text {pre }}\right)\right]+\left[p_{\text {hha }}^{\text {post }}\left(x^{\text {post }}\right)-p_{\text {hha }}^{\text {post }}\left(x^{\text {pre }}\right)\right]$

\footnotetext{
5 Cost sharing for patients did not change so changes in admission probabilities are unlikely to change from the patient side.
} 
The first term in equation (8) represents the admission policy effect - changes in the probability of admission holding the acute discharge cohort constant. The second term in (8) represents the composition effect - changes in the probability of admission from changes in the characteristics of individuals discharged from acute care hospitals, holding admission policies constant.

We separately estimate the "admission policy" and "composition" effects in equation (8). First, we model home health admissions in each quarter of the data as a function of health, demographic, provider, and geographic characteristics described in the data section above using a probit model, for each quarter $q$ of our data in the pre and post policy change periods, as in (9).

$$
\operatorname{prob}^{q}\left(\operatorname{any} H H A=1 \mid x_{i}\right)=\Phi\left(\alpha^{q}+\beta^{q} X_{i}\right)
$$

The separate estimates of $\alpha$ and $\beta$ for each quarter are then used to construct an "admission simulator." We apply the coefficient estimates from each quarter to a constant cohort of acute-care discharges: for the IPS this quarter is the first quarter of 1996, for the PPS this cohort is from the first quarter of 1999. We create a synthetic panel of simulated admission probabilities, such that the sample is held constant and only the policy rules (as a function of observable characteristics) change.

We then estimate interrupted time-series models as in (10), regressing projected home health probabilities on a linear quarterly trend and indicator variables for the seven quarters following each policy change.

$$
p_{i t}^{q}=\alpha+\eta Q u a r t e r+\sum_{k=1}^{7} \theta_{k} \text { Post }_{k}+u_{i t}
$$

The estimates of $\theta$ represent average differences (relative to the counterfactual quarterly time trend) in simulated admissions in each quarter after the policy change for the base cohort.

To estimate the "composition" effect, we apply the "admissions simulator" from the last quarter of each sample (representing the post-IPS/PPS admissions policy) to each successive cohort of acute discharges. We then estimate equation 
(10), but this time the estimates of $\theta$ represent changes in admissions stemming from changes in the composition of patients discharged from acute hospitals.

Next, we examine changes in costs of patients seen in home health agencies. Changes in costs can change based on home health agencies' treatment policies (the shift from $c^{\text {pre }}$ to $c^{\text {post }}$ to in equation 11), and from changes in the composition of patients in home health agencies (the shift from $x^{\text {pre }}$ to $x^{\text {post }}$ in equation 11).

$$
\Delta c_{h h a}=c_{h h a}^{\text {post }}\left(x^{\text {post }}\right)-c_{\text {hha }}^{\text {pre }}\left(x^{\text {pre }}\right)
$$

Our goal is to disentangle treatment policy changes from shifts in the composition of patients seen in home health agencies. Equation (11) can be equivalently rewritten as in (12):

$$
\Delta c_{\text {hha }}=\left[c_{\text {hha }}^{\text {post }}\left(x^{\text {pre }}\right)-c_{\text {hha }}^{\text {pre }}\left(x^{\text {pre }}\right)\right]+\left[c_{\text {hha }}^{\text {post }}\left(x^{\text {post }}\right)-c_{\text {hha }}^{\text {post }}\left(x^{\text {pre }}\right)\right]
$$

The first portion of equation (12) represents changes in costs in home health agencies due to changes in treatment policy, and the second portion represents changes in costs due to changes in the composition of patients seen in home health agencies (i.e. the selection effect).

We separately estimate treatment and selection effects. First, we model costs incurred by home health agencies as a function of individual, provider, and geographic characteristics (the same as those used for modeling admission policies) for home health agencies patients separately for each quarter using OLS, as in (13).

$$
\operatorname{Costs}_{j}^{q}=\alpha^{q}+\beta^{q} X_{i}
$$

The separate estimates of $\beta$ and $\alpha$ for each quarter are then used to create a "treatment simulator," projecting costs in each quarter of the sample (pre and post- reimbursement policy change) for a fixed cohort of home health patients. We then estimate an interrupted time series model, as in (14). The subsequent $\delta$ estimates can then be used to trace out changes in conditional costs due solely to 
changes in treatment policy, isolated from changes in home health agencies' patient composition from selection.

$$
c_{i t}^{q}=\alpha+\eta Q \text { uarter }+\sum_{k=1}^{7} \delta_{k} \text { Post }_{k}+u_{i t}
$$

To estimate the "selection" effect, we apply a treatment simulator from a single and constant quarter to each successive cohort of home health patients. These projected costs only demonstrate changes due to selection, as the treatment simulator is held constant. We estimate models like that in (14), but this time the coefficient estimates indicate changes in costs coming from selection.

Changes in admission and treatment policies in home health agencies could potentially impact acute readmissions and patient health outcomes. We use a similar empirical strategy to examine effects on readmission probabilities and patient health outcomes. In a sensitivity analysis, we examine differences in home health admissions, costs, and outcomes between hospital service areas experiencing larger and smaller payment changes after the IPS, similar to that in McKnight (2006).

Finally, we investigate heterogeneous changes in costs and admission probabilities across patients with heterogeneous changes in payments. For this, we again create a synthetic panel and regress changes in projected home health costs or admissions (as a function of observable characteristics) on changes in home health payments before and after each payment reform.

\section{Results}

Our results section proceeds as follows. First we examine the effects of payment reforms on Medicare payments to home health agencies, home health agency costs, and admissions. Next, we examine effects on acute readmissions and health outcomes. We perform sensitivity analyses comparing changes in outcomes in hospital service areas with larger and smaller changes in payment after the IPS. Finally, we investigate the presence of heterogeneous effects of the 
IPS and the PPS on home health agency costs and admissions by patients with differential changes in average payments.

\subsection{Effects of IPS and PPS on home health payments, costs, and admissions}

We begin by graphically examining the effects of reimbursement policy changes. Figure 2 shows treatment and admission policy effects of the IPS and PPS for stroke patients. In each case, the solid line represents the mean "simulated" value for each quarter in the synthetic panel, where the patient cohort includes patients from the first quarter of 1996 (for the IPS) or the first quarter of 1999 (for the PPS) and outcomes are simulated for each subsequent quarter, using quarter-specific probit estimates for admission probabilities or OLS estimates for payments and costs. This approach allows us to focus on change due solely to changes in treatment and admissions policies (as a function of patients' observable characteristics), as opposed to changes in the composition of patients in home health agencies or composition of patients discharged from acute care. The dashed line represents a quarterly linear time trend estimated in the pre-policy change period, representing the counterfactual trend in the post-policy change period. Finally, the dotted line represents actual average outcomes in each quarter.

\section{Payments}

Figure 2a traces out home health payments before and after the IPS implementation. After remaining constant over the pre-IPS period, average home health payments fell substantially after the IPS, from over $\$ 2,800$ to under $\$ 2,200$ for stroke patients. In contrast, after the Home Health PPS average Medicare payments to home health agencies for stroke patients increased considerably relative to the pre-reform trend (Figure $2 \mathrm{~b}$ ). Table $2 \mathrm{a}$, Panel 1 displays estimates from regressing simulated payments on indicators for the first seven quarters after the IPS and the PPS, controlling for a quarterly trend. By the second year after the IPS, payments were reduced by approximately $\$ 750$; after the PPS, payments had increased by a similar amount. Tables $2 \mathrm{~b}$ and $\mathrm{c}$ present IPS and PPS payment 
effects for hip fracture and joint patients and exhibit larger PPS effects relative to the IPS effects.

\section{Costs}

Figures $2 \mathrm{c}$ and $2 \mathrm{~d}$ show costs simulated in each quarter for a constant crosssection of home health patients before and after the IPS and PPS. Figure $2 \mathrm{c}$ shows a reduction in costs after the IPS, from over $\$ 3,000$ in the first quarter of 1997 to under $\$ 2,600$ at the end of 1999 , mirroring the decline in average payments to home health providers in Figure 2a. However, while average payments increased after the PPS, costs increased only a marginal amount relative to the counterfactual trend (in Figure 2d). Table 2a, Section 2 shows this in greater detail. Although the decrease in costs after the IPS was comparable to the decrease in average payment, the increase in costs after the PPS was only around $1 / 3$ of the increase in payments for stroke patients. Table $2 b$ exhibits similar patterns for hip fracture. In Table 2c, increases in resource use for joint replacement placement after the PPS are larger in magnitude than post-IPS decreases, but still small in proportion to the increase in home health payments.

\section{Admissions}

Figures $2 \mathrm{e}$ and $2 \mathrm{f}$ show admissions over the simulated panel. The probability of using home health services decreased by over 6 percentage points after the IPS, again coinciding with the decrease in Medicare reimbursement. However, home health admissions actually decreased further after the PPS for stroke patients, despite the increased average generosity towards home health agencies. Similar patterns are exhibited for hip fracture and joint replacement patients in Tables $2 \mathrm{~b}$ and $\mathrm{c}$, Section 3 .

Figure 2 and Table 2 show that the IPS and PPS had similar magnitude effects on Medicare payments to home health agencies (with the IPS reducing and the PPS increasing payments); however, while the IPS substantially decreased home health costs and probability of use, the PPS led to smaller increases in costs 
and actually decreased use of home health (for the tracer conditions in our sample). These asymmetries may be due to the change in marginal reimbursement under these systems. The IPS decreased both average and marginal reimbursement, while the PPS increased average reimbursement but further decreased marginal reimbursement. These results show the relative importance of average and marginal reimbursement in determining providers' admissions and treatment policies. Although we do not quantify the reduction in marginal reimbursement after the PPS, it may have offset the increased Medicare generosity in determining costs and visits per patient, and more than offset increased payments in the determination of home health agencies' admission policies for stroke, hip fracture, and joint replacement patients.

\section{Selection}

Home health costs could also change due to selection; that is, the composition of patients using home health services could change with reimbursement policy. Similarly, the probability of home health use could change with the composition of patients discharged from acute care hospitals. As explained above, we examine selection by estimating OLS and probit regressions expressing costs and probability of home health use as a function of patient, provider, and geographical characteristics in the last quarter of each sample (1999 q2 for the IPS, 2002 q2 for the PPS), and then applying these coefficient estimates to each home health patient cohort and acute hospital discharge cohort to simulate home health costs and admissions (respectively). In this case, treatment and admission policies are held constant, but the cohorts differ. Thus, changes in costs and admissions are attributable to changes in patient composition. However, Figure 3 (and the similarity between actual and simulated outcomes in Figure 2) implies that changes in patient composition had small effects on Medicare reimbursement, home health costs, and home health admissions for stroke patients 
after both the IPS and the PPS. Table 3 shows similarly small effects across stroke, hip fracture, and joint replacement patients.

These results imply that little "cream skimming" based on observable characteristics occurred in home health agencies. However, if there were changing unobservable characteristics, then our treatment and admission policy estimates may also reflect such selection. However, given the fact that we observe little selection occurring based on observable characteristics suggests that unobservable characteristics, which are likely correlated with observable characteristics, also stay constant over this period.

In Appendix Figure 1, we examine changes in patient composition more directly by plotting the fraction of home health patients with three or more comorbidities versus no comorbidities, and two or more complications versus zero complications ${ }^{6}$. We find smooth trends (with some seasonality) in these outcomes in each quarter over the sample period, with little obvious change after either reform.

The estimates thus far have examined changes in composition occurring within tracer conditions. Next, we investigate the changes in composition occurring across tracer conditions. Appendix Figure 2 plots the relative fractions of hip fracture, stroke, and joint replacement patients in home health agencies and implies increases in joint replacement patients relative to hip and stroke patients. We present selection estimates in Figure 4 and Table $3 \mathrm{~d}$ that pool acute discharges and home health patients across the three tracer conditions, and thus

\footnotetext{
${ }^{6}$ Complications are from the preceding acute stay and may include post-operative pulmonary compromise; post-operative gastrointestinal hemorrhage; cellulitis or decubitus ulcer; septicemia; pneumonia; mechanical complications due to a device, implant, or graft; shock or arrest in the hospital; post-operative myocardial infarction; post-operative cardiac abnormalities other than AMI; procedure-related perforation or laceration; venous thrombosis and pulmonary embolism; acute renal failure; miscellaneous complications; delirium; and dementia (a selection of complications pertinent to post-acute care utilization selected from Iezzoni (1994)).
} 
exhibit changes in costs and admissions reflecting changes in composition both within and across tracer conditions. These estimates show only small changes in costs and admissions (of mixed direction and statistical significance), implying minimal changes in costs or admissions from changes in composition across tracer conditions among acute discharges and home health patients.

\subsection{Effects of IPS and PPS on acute readmissions and mortality}

Reductions in home health costs and admissions may have impacts on patient health outcomes. To examine this, we estimate the impact of the IPS and PPS on acute readmissions within 90 days following acute discharge. Because we found little evidence of changes in costs or admissions stemming from patient composition, we only simulate changes in outcomes for a constant cohort of patients. Specifically, we estimate the probability of death or readmission in each quarter as a function of observable characteristics, and project the coefficient estimates from each quarter to a constant patient cohort. Figure 5 plots simulated acute readmissions and mortality (within a 90 day post-acute episode in each case) for stroke patients before and after the IPS and PPS. In Tables 4 and 5, reflecting the seasonality of these measures, we regress simulated outcomes on indicators for calendar quarter, calendar quarter interacted with "POST" reform indicators, and a linear time trend. The figures show little change in patient outcomes after each reform. While the POST-quarter interactions are often statistically significant, they are small in magnitude and in conflicting directions. While these estimates suggest that there was little effect of either home health payment reform on mortality and readmissions, we cannot rule out effects on more intermediate outcomes such as functional status that we are unable to measure in our data. However, large effects on functional status may be unlikely given the strong association between functional status and mortality (Scott et al. 1997). 


\subsection{Geographic variation in Home Health IPS}

Our main analyses estimate the impacts of payment reform on Medicare payments, costs, admissions, and other outcomes by comparing post-reform changes to a pre-reform linear time trend. For example, following the Home Health IPS, we find sharp breaks in the pre-reform time trend for payments, admissions, and costs, but no break in trends for mortality and readmissions. However, to definitively distinguish the effects of policy impacts from other contemporaneous trends, we require exogenous treatment and control groups. While such a control group does not exist (as far as we know) for the Home Health Prospective Payment System, per-patient visit limits for Medicare reimbursement after the Interim Payment System were based in part on an agency's historical average (75\%), and in part on the average visits per patient across an agency's census division. Thus, facilities with average per-patient visits above the division average will experience greater reduction in Medicare reimbursement than facilities below the division average ${ }^{7}$. Similarly, patients in geographical areas with facilities that provided, on average, higher than their division's average number of visits will be exposed to a greater reduction in reimbursement than patients in geographic areas with facilities below their division's average number of visits. We plot simulated payments, costs, and admissions separately for stroke patients in hospital service areas (defined by Dartmouth (1996)) that are above and below their respective census division means in Figure 6. In this case, we simulate payments, costs, home health admissions, and outcomes in each quarter separately for two base cohorts of patients (acute discharges in 1996 q1) living in hospital service areas with average numbers of visits above and below their census division average ${ }^{8}$. Thus, within

\footnotetext{
${ }^{7}$ McKnight (2006) exploits this variation to examine intensity of care after the IPS.

${ }^{8}$ A small number of hospital service areas have no home health agencies, as a result approximately 8 percent of observations are dropped for these analyses.
} 
each cohort over time variation comes in admission and treatment policies (as a function of patients' observable characteristics), and changes in admission and treatment policies may vary between above and below-division mean hospital service areas.

Figure 6a shows a narrowing of home health payments after the IPS in the above and below division mean hospital service areas (for stroke patients), although the common payment reduction is larger than the differential change. Figures $6 \mathrm{~b}-\mathrm{f}$ shows that this narrowing also occurs for home health costs, but not for the probability of home health use, acute readmission or mortality. Estimates from the regression analog of Figure 6 are displayed in Table 6 . These specifications are similar to those in equations (10) and (14), except that the post indicators are interacted with an "above division mean" indicator variable and we include time (year-quarter) fixed effects instead of a quarterly trend.

Table 6, Columns 1-3, show that the decrease in payments and costs ranges between $\$ 50$ and $\$ 125$ larger for patients in above-division-mean hospital service areas (where the total average reduction was $\$ 750$ for stroke patients). As in Figure 8, there is a differential reduction in costs for above-division health service areas, but small and mixed effects on home health admissions, acute readmissions, and mortality during the 90-day episode. Appendix Tables $1 \mathrm{a}$ and $\mathrm{b}$ show similar patterns for hip fracture and joint replacement patients. These estimates imply that reductions in treatment intensity, in particular, did not increase readmission rates or mortality.

\subsection{Heterogeneous effects}

To investigate the relative importance of average versus marginal reimbursement, we investigate heterogeneity in the effects of reform by average payment change. While changes in overall payments after reforms may vary across patients, changes in marginal payments are more homogenous across patients. Thus, to the extent that changes in average payments are related to 
changes in admissions or costs, this may reflect the effects of average, as opposed to marginal, reimbursement on provider behavior. If changes in costs and admissions are not related to the changes in average payment, this may signal uniform changes in intensity and volume related to changes in marginal reimbursement.

In Table 7, we again create a synthetic patient panel and regress perpatient simulated changes in home health costs and admissions as a function of changes in simulated home health payments, in each case between 1996 quarter 1 and 1999 quarter 2 (for the IPS) and between 1999 quarter 1 and 2002 quarter 2 (for the PPS). In Table 7a, we find mixed effects of payment changes on probability of home health use across tracer conditions after the IPS. However, we show that changes in payments are positively related to changes in conditional costs, as well as unconditional costs. In Table $7 \mathrm{~b}$, we show similarly mixed effects on probability of admission after the PPS, again with strong positive relationships between payments and costs. This result implies that patients exhibiting the largest increases in payments after the PPS received the largest increase in treatment intensity (costs). Thus, these estimates imply that average payments are also an important determinant of treatment intensity, but are less strongly associated with admissions.

\section{Conclusion}

In this paper we examine the effects of changes in Medicare reimbursement for home health agencies, including the Interim Payment System (IPS) in 1997 and the Prospective Payment System (PPS) in 2000. We build upon previous research by creating a unified framework to contrast these two unique changes in payment policy: one reducing both marginal and average reimbursement, the other increasing average reimbursement while reducing marginal reimbursement. We develop a conceptual model that predicts the 
decreases in both marginal and average reimbursement characterizing the IPS will lower both the volume of patients in home health agencies and intensity of treatment, but that offers ambiguous predictions for the PPS due to offsetting positive changes in average reimbursement but further reductions in marginal reimbursement. We employ an empirical approach that separates changes in costs and admissions due to home health agencies' admissions and treatment policies, and those due to the composition of patients discharged from acute care hospitals and admitted to home health agencies. We examine the impacts of the IPS and the PPS on acute readmissions and mortality. Finally, we investigate the presence of heterogeneous effects based on differential changes in average reimbursement, to further gauge the relative importance of marginal and average reimbursement.

Consistent with our conceptual model, our estimates show that the IPS decreased home health costs and admissions. However, despite the substantial increase in reimbursement offered by the PPS, costs (resource use) increased only slightly and admissions actually decreased for the tracer conditions in our sample. For both the IPS and the PPS, we find little evidence of "cream skimming" based on the observable characteristics in our data. Both payment reforms had limited effects on acute readmissions and mortality. However, it may be the case that more intermediate outcomes such as functional gain not present in our data were affected by changes in treatment intensity and admission policies. Changes in per-patient average reimbursement did predict resource use, and to a lesser extent probability of admissions. However, in the PPS, increases in average reimbursement were almost totally offset by reductions in marginal reimbursement with respect to treatment intensity, and changes in marginal reimbursement completely offset increased average reimbursement with respect to admissions, implying that provider behavior may be more responsive to reimbursement at the margin. 
Our results suggest that reforms such as bundled payments and accountable care organizations that further reduce marginal reimbursement are likely to impact provider behavior. However, the level of payment is also important; if increased, reductions in resource use will translate to higher margins for providers (as in the PPS) rather than savings to Medicare (as in the IPS). 


\section{References}

Centers for Medicare and Medicaid Services. Bundled Payments for Care Improvement Initiative: Fact Sheet. August 23, 2011. http://innovations.cms.gov/documents/pdf/Fact-Sheet-Bundled-PaymentFINAL82311.pdf (last accessed 1/26/12)

Dartmouth Medical School. The Dartmouth Atlas of Health Care, 1996. Chicago, AHA Press.

Elixhauser A, Steiner C, Harris DR, Coffrey RM. Comorbidity measures for use with administrative data. Medical Care, 1998; 36(1): 8-27.

Ellis RP, McGuire, TG. Hospital response to prospective payment: moral hazard, selection, and practice-style effects. Journal of Health Economics. 1996; 15: 257 277.

Grimaldi PL. Prospective rates for episodes of home health care. Journal of Health Care Finance. 2002; 28(3):63-75.

Hodgkin, D and McGuire TG. Payment levels and hospital response to prospective payment. Journal of Health Economics, 1994; 13: 1-30

Iezzoni, L.I., Daley, J., Heeren, T., et al. Identifying complications of care using administrative data. Medical Care. 1994; 32(7): 700-715.

McCall N, Komisar H, Petersons A, and Moore S. Medicare home health before and after

the BBA. Health Affairs, May/June 2001, Vol. 20, No. 3, p. 189-198.

McCall N, et al. Utilization of home health services before and after the Balanced Budget Act of 1997: what were the initial effects? Health Services Research. 2003b: 38(1): 85-106.

McKnight R. Home care reimbursement, long-term care utilization, and health outcomes. Journal of Public Economics. 2006; 90: 293-323.

Medicare Payment Advisory Commission. Home health services. Report to the Congress: Medicare Payment Policy. March 2002

Medicare Payment Advisory Commission. Home health care services payment system. Payment Basics, October 2010 (a). 
Medicare Payment Advisory Commission. Home health services. Report to the Congress: Medicare Payment Policy, March 2010 (b).

Newhouse J. Pricing the priceless: a health care conundrum. Cambridge (MA): The MIT Press; 2002.

Porel FW, Liu K, Brungo DB. Agency and market area factors affecting home health agency supply changes. Health Services Research. 2006; 41(5): 1847-1875.

Schlenker RE, Powell MC, and Goodrich GK. Initial home health outcomes under prospective payment. Health Services Research. 2005; 40(1): 177-194.

Scott WK, Macera CA, Cornman CB, Sharpe PA. Functional health status as a predictor of mortality in men and women over 65. Journal of Clinical Epidemiology. 1997; 50(3): 291-296.

Sood N, Huckfeldt P, Escarce J, Grabowski DC, Newhouse JP. The effect of prospective payment on admission and treatment policy: evidence from inpatient rehabilitation facilities. NBER Working Paper 17125; 2011. 
Figure 1. Average Medicare home health payments conditional on use

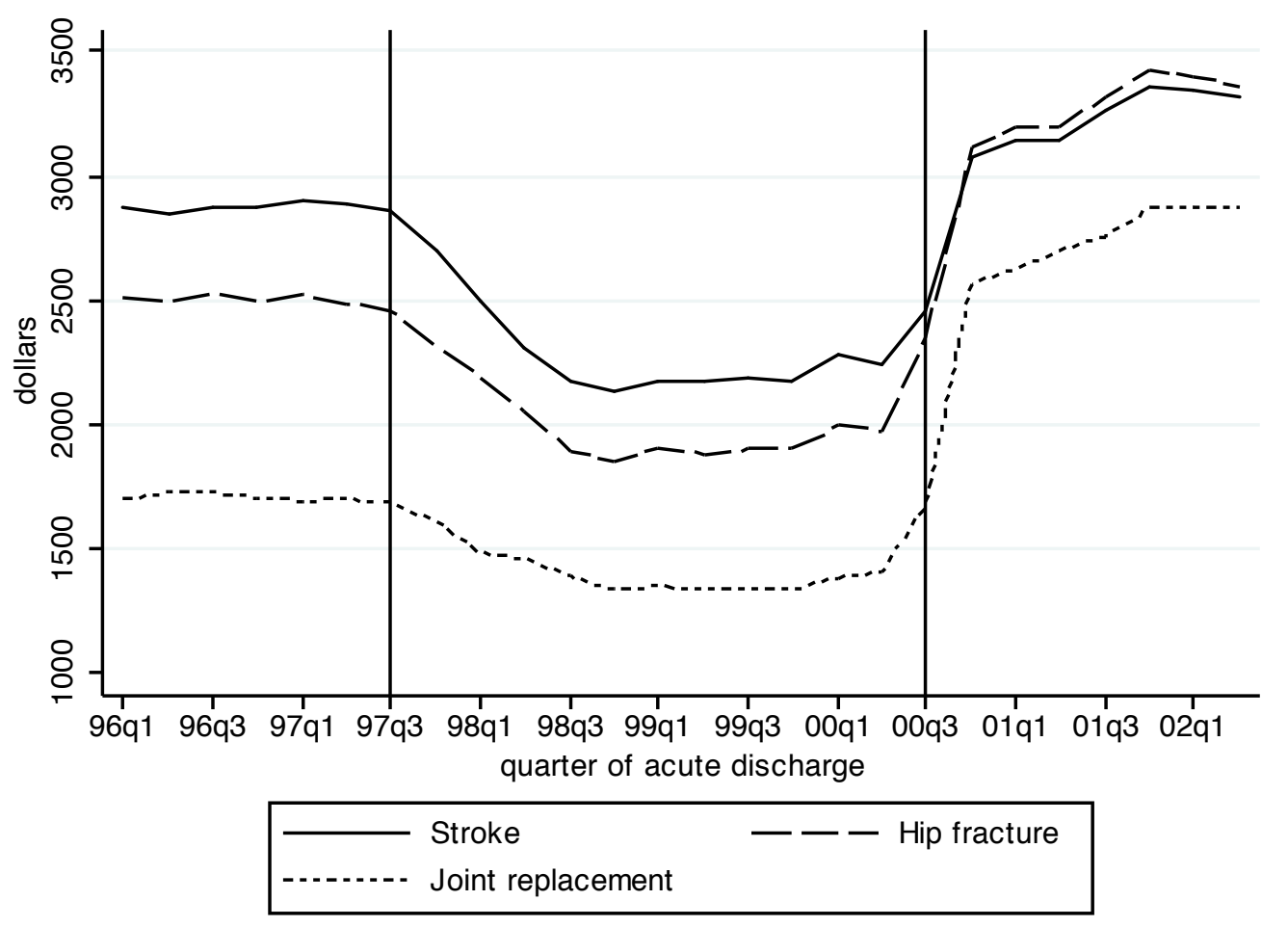

Note: Figure shows average Medicare Fee-For-Service payments across 90-day post-acute episodes starting in each quarter between 1996q1 and 2002 q2 for stroke, hip fracture, and joint replacement patients. The first vertical line indicates quarter before Home Health IPS (10/1997). The second vertical line indicates the quarter prior to the Home Health PPS (10/2002). 
Figure 2. Treatment and admission effects of Home Health Interim Payment System (IPS) and Prospective Payment System (PPS) on home health payments, costs, and admissions (stroke patients)

a. IPS: home health payments

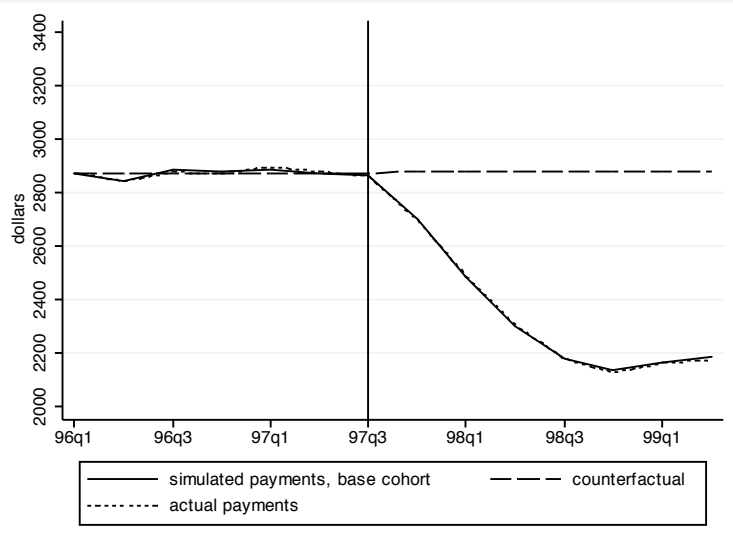

c. IPS: home health costs

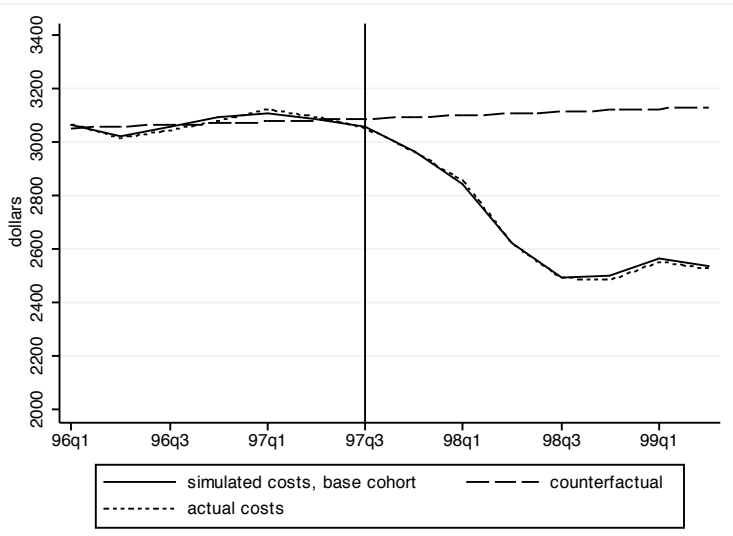

b. PPS: home health payments

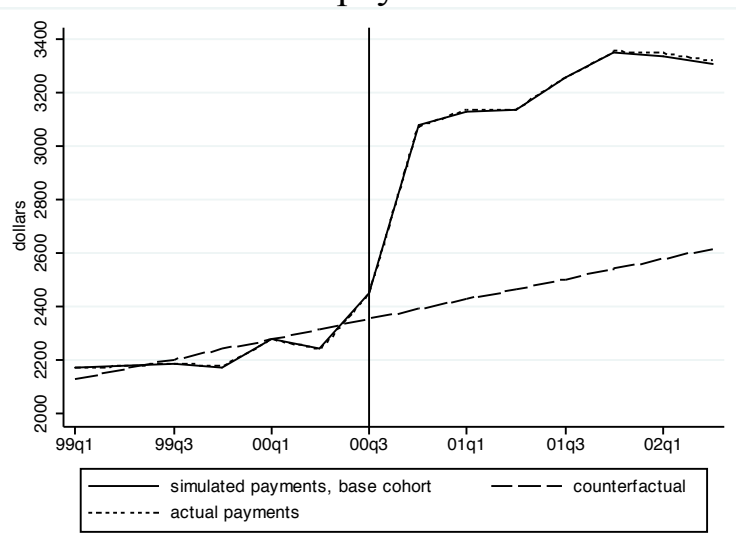

d. PPS: home health costs

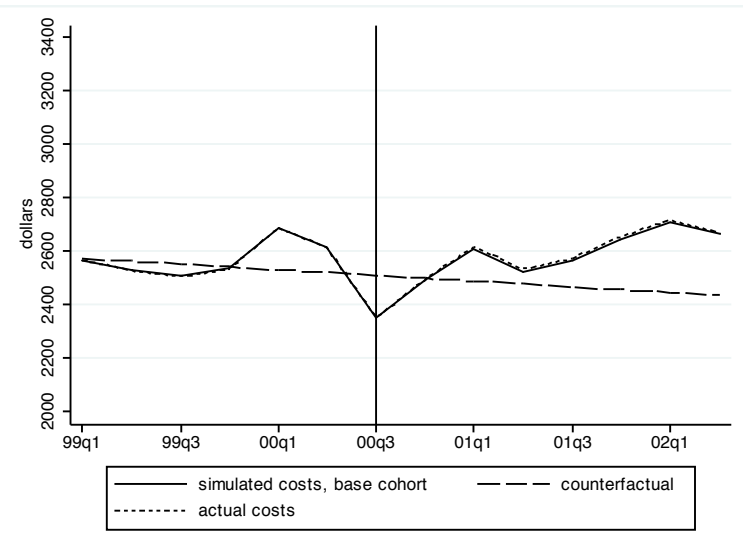


e. IPS: home health admissions for $96 \mathrm{q} 1$ acute discharges

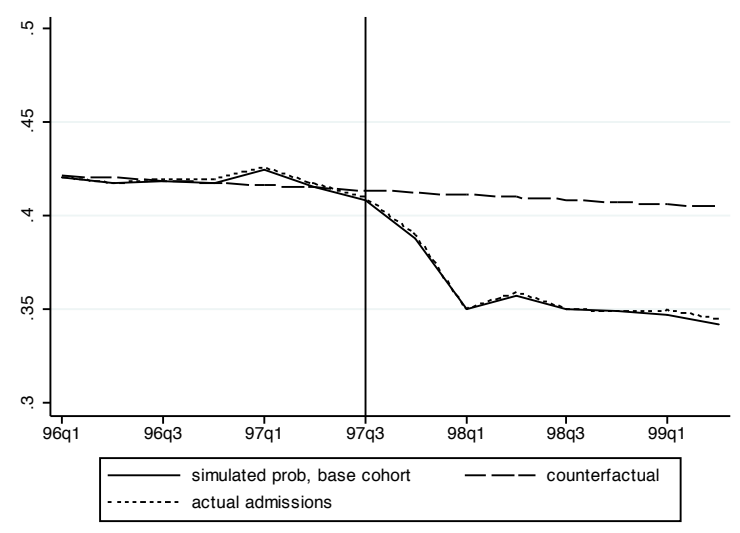

f. PPS: home health admissions for $99 \mathrm{q} 1$ acute discharges

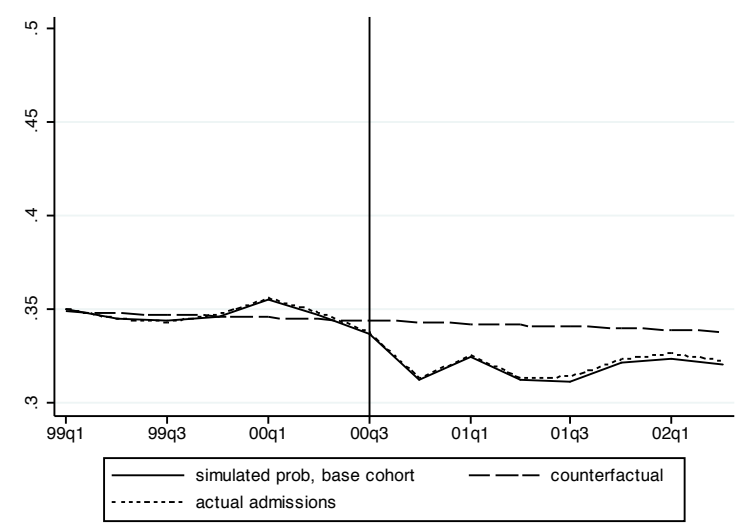

Note: Measures calculated from 100\% Medicare Home Health claims data. Solid line indicates average simulated measures for each quarter. Dashed line indicates pre-IPS or PPS trend. Dotted line indicates actual means. Base cohort for IPS simulated values includes home health patients discharged from acute care for stroke in the first quarter of 1996 (for payments and costs) and all acute discharges for stroke (for admissions). Base cohort for PPS simulated values includes home health patients discharged from acute care in the first quarter of 1999 (for payments and costs) and all acute discharges for stroke (for admissions). Vertical line in IPS graphs indicates quarter prior to Interim Payment System implementation, for PPS graphs quarter prior to Prospective Payment System implementation. 
Figure 3. Selection effects for treatment and admissions for Home Health (HH) Interim Payment System (IPS) and Prospective Payment System (PPS) (stroke patients)

a. IPS: 99q2 payments simulated for each $\mathrm{HH}$ cohort

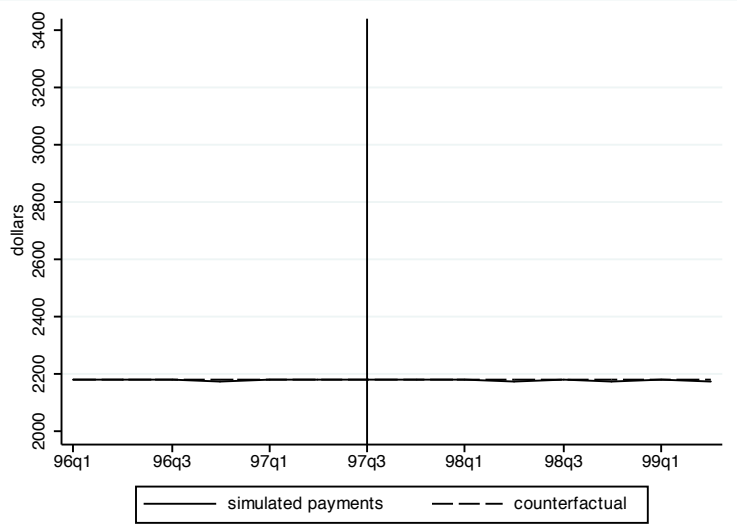

c. IPS: 99q2 costs simulated for each HH cohort

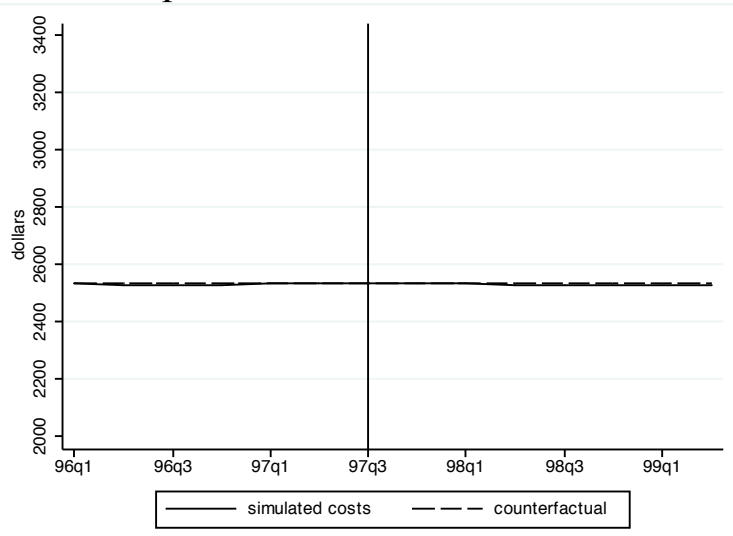

b. PPS: 02q2 payments simulated for each $\mathrm{HH}$ cohort

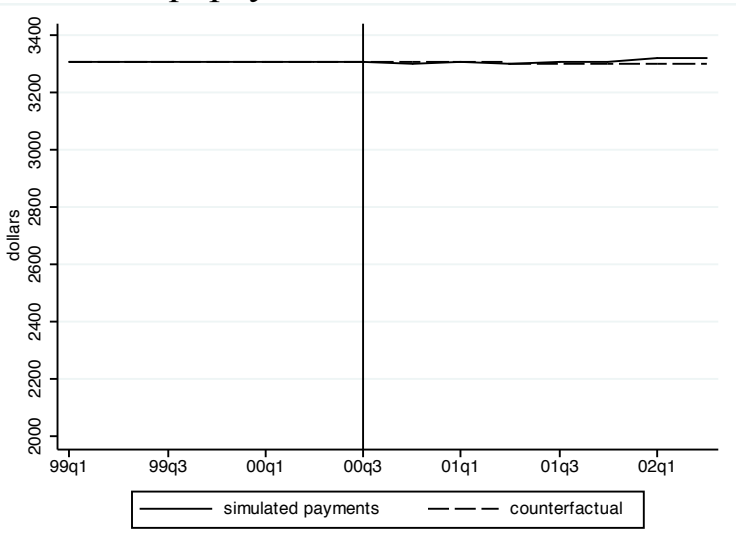

d. PPS: 02q2 costs simulated for each $\mathrm{HH}$ cohort

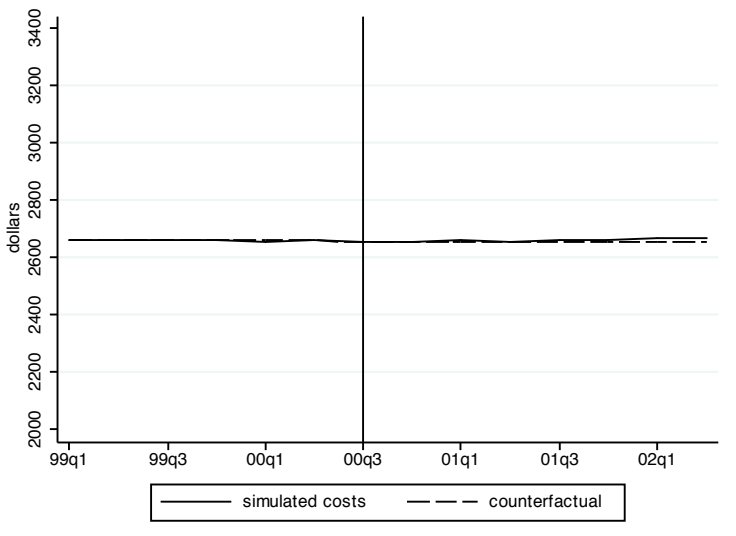


e. IPS: $99 \mathrm{q} 2$ admits simulated each discharge cohort

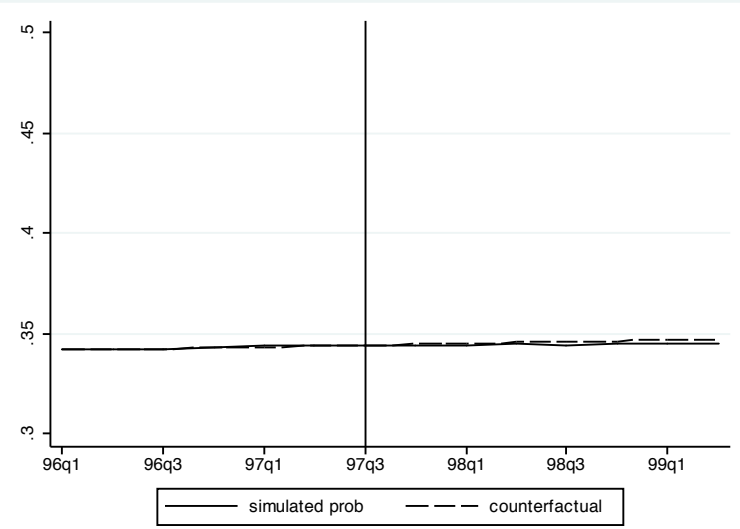

f. PPS: 02q2 admits simulated for each discharge cohort

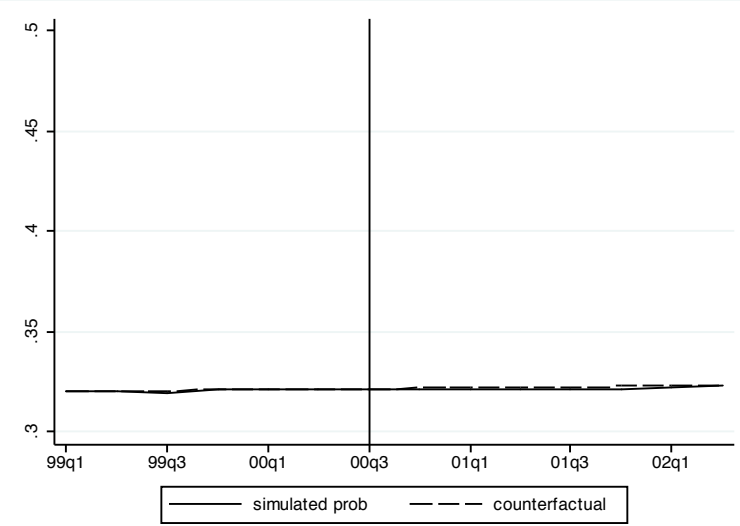

Note: Measures calculated from 100\% Medicare Home Health claims data. Solid line indicates average simulated measures for each quarter. Dashed line indicates pre-IPS or PPS trend. Vertical line in IPS graphs indicates quarter prior to Interim Payment System implementation, for PPS graphs quarter prior to Prospective Payment System implementation. 
Figure 4. Selection estimates for pooled sample (acute discharges for stroke+hip+lower extremity joint replacement)

a. IPS: 99q2 costs simulated for each $\mathrm{HH}$ cohort

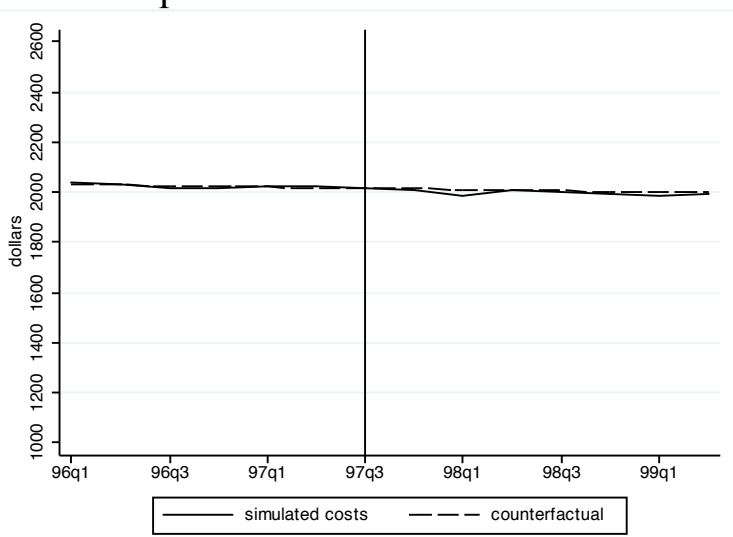

c. IPS: $99 \mathrm{q} 2$ admits simulated for each discharge cohort

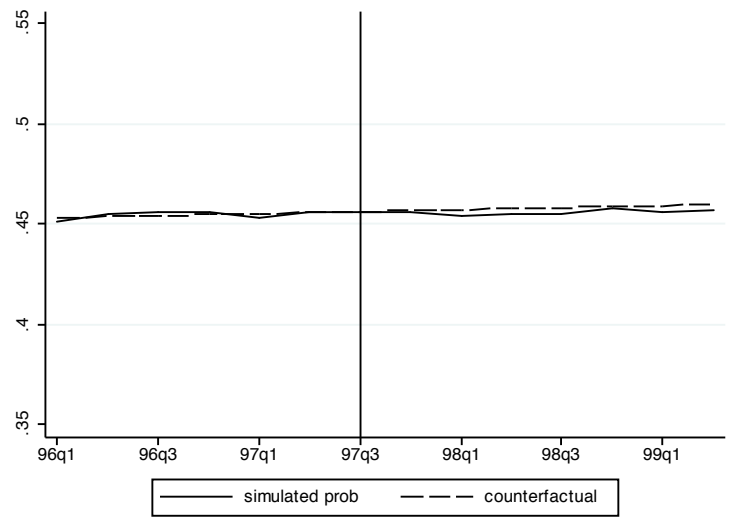

b. PPS: 02q2 costs simulated for each HH cohort

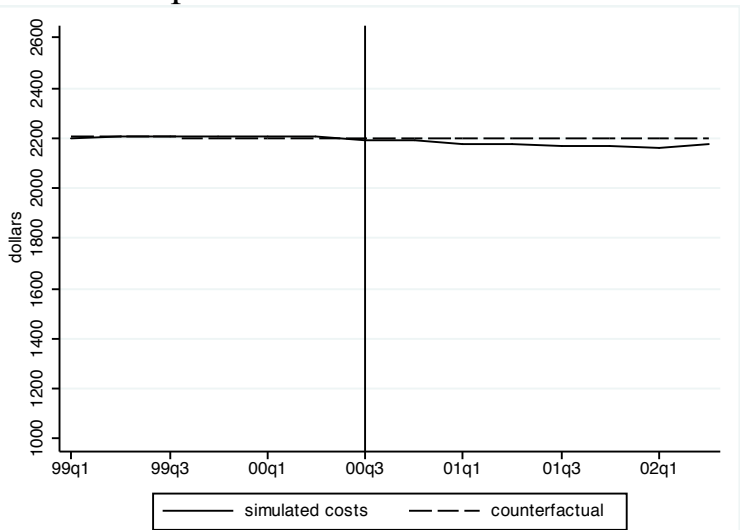

d. PPS: 02q2 admits simulated for each discharge cohort

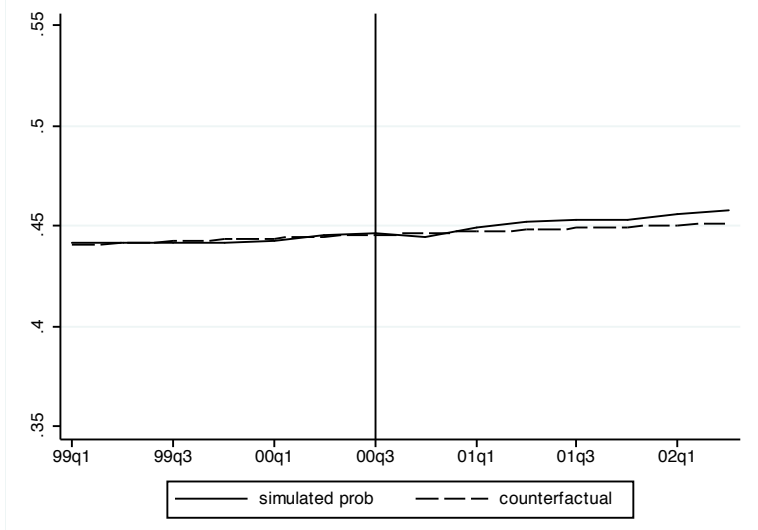


e. IPS: Coef of var for simulated costs and admissions

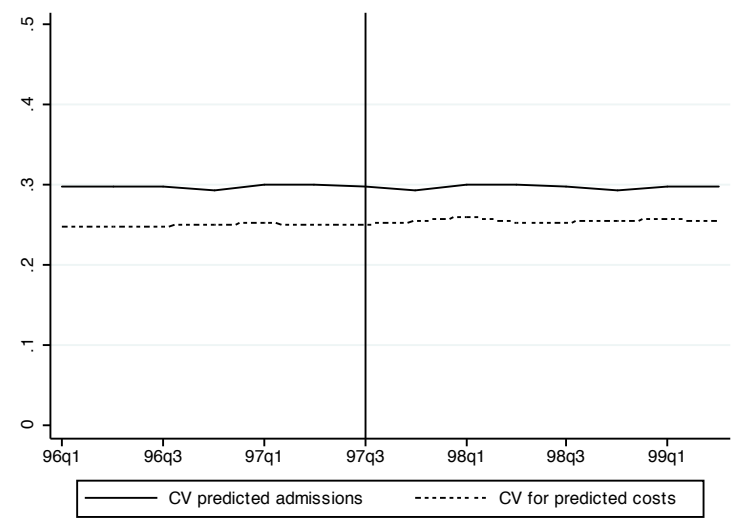

f. PPS: Coef of var for simulated costs and admissions

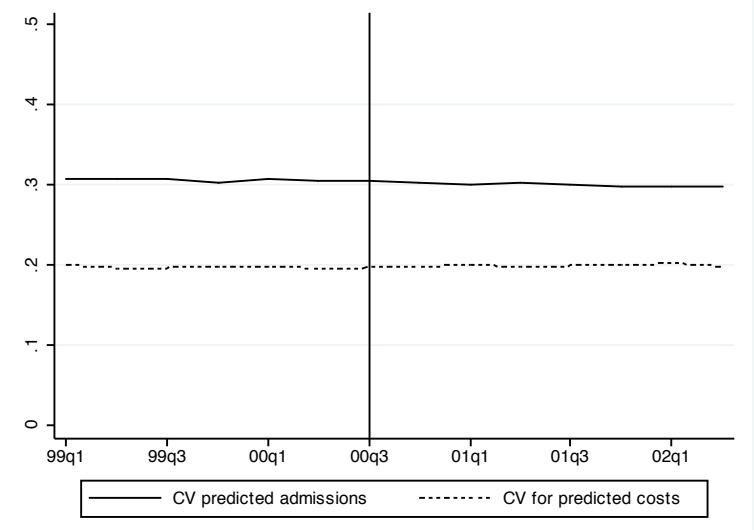

Note: Measures calculated from 100\% Medicare Home Health claims data. For a-d: Solid line indicates average simulated measures for each quarter. Dashed line indicates pre-IPS or PPS trend. For e-f: Solid line indicates coefficient of variation for home health predicted admissions and dotted line indicates coefficient of variation for home health predicted costs. 
Figure 5. Simulated changes in outcomes

a. IPS: readmission

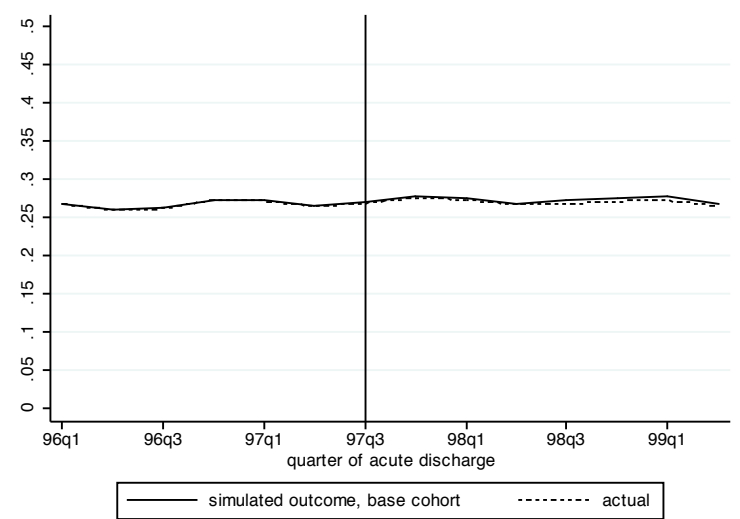

c. IPS: mortality

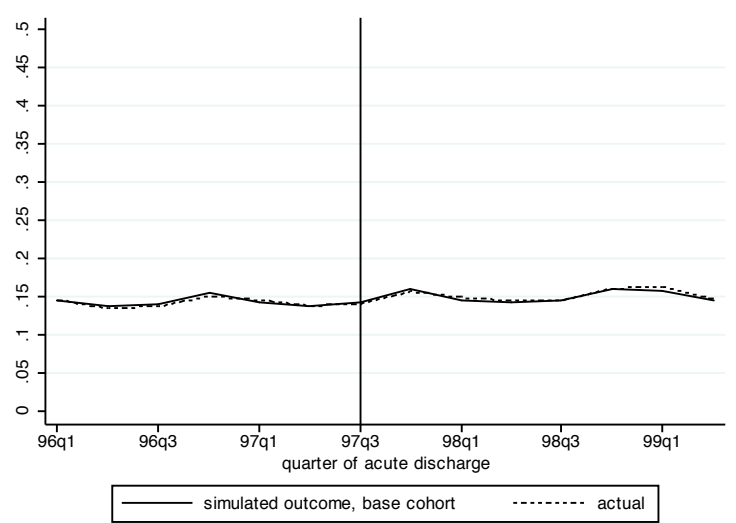

b. PPS: readmission

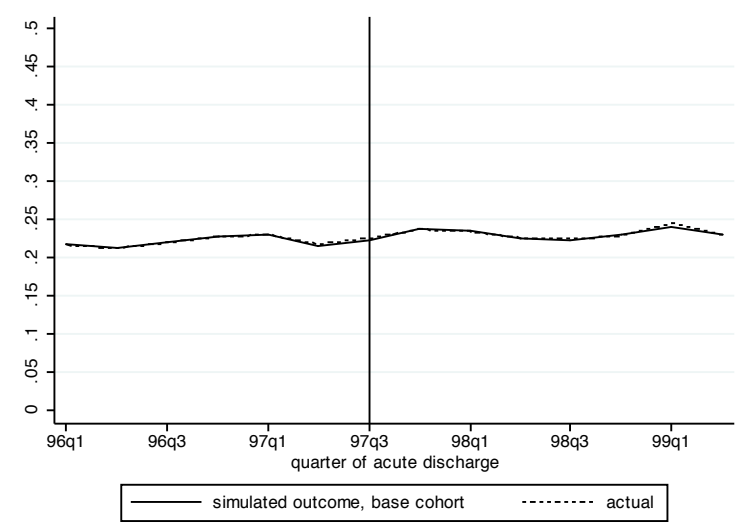

d. PPS Mortality

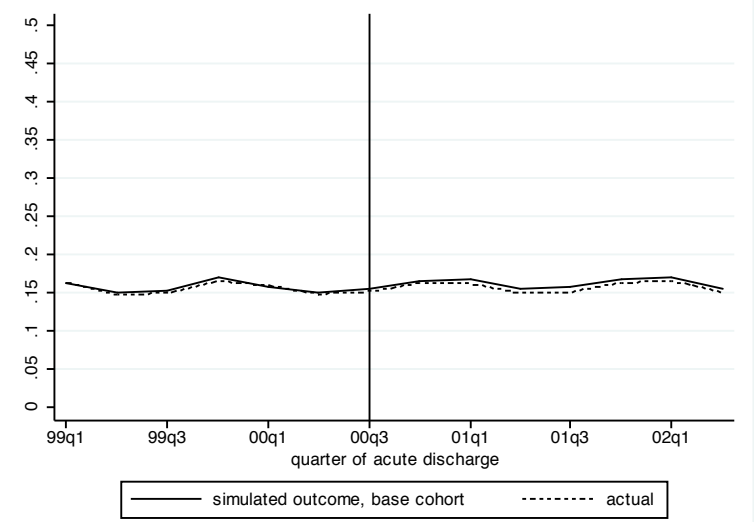

Note: Solid line indicates average simulated measures for each quarter. Patient cohort is 96 q1 acute discharges for IPS, 99 q1 acute discharges for PPS. Dotted line indicates actual average health outcomes. Vertical line for IPS graphs indicates quarter prior to Home Health IPS implementation, for PPS graphs quarter prior to Home Health PPS implementation. 
Figure 6. Simulated outcomes for hospital service areas above and below Census Division mean visits in 1996

a. IPS: payments

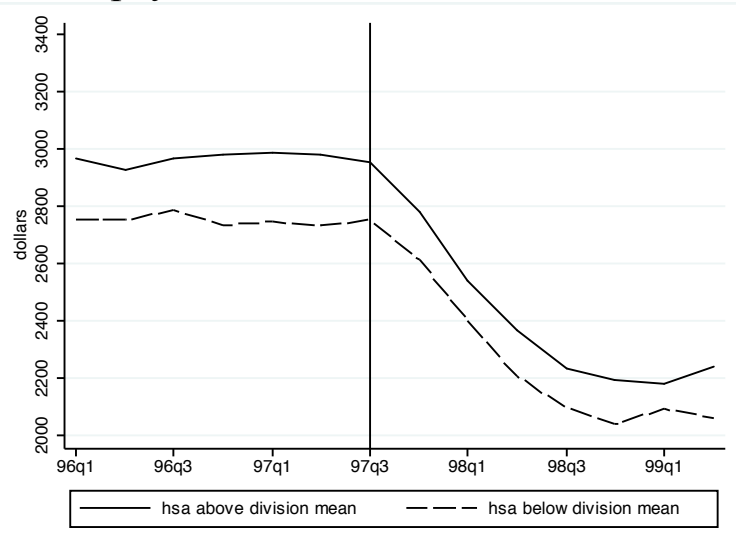

d. IPS: admissions

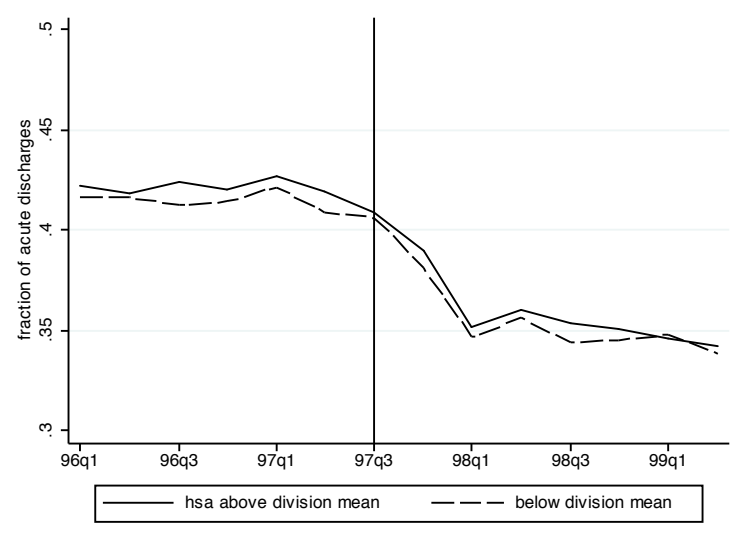

b. IPS: costs

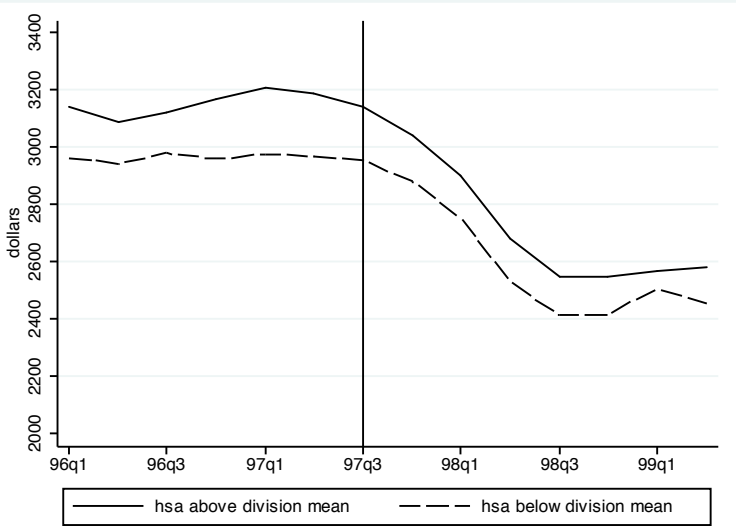

e. IPS: Hospital readmissions

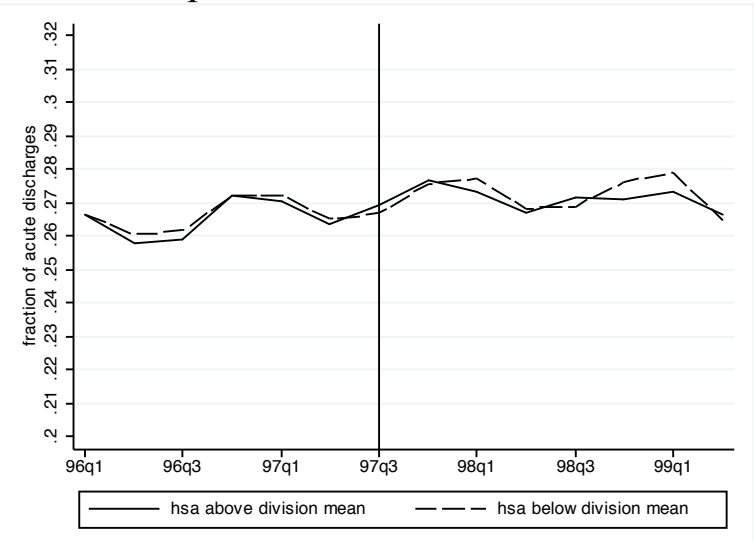




\section{f. IPS: Mortality}

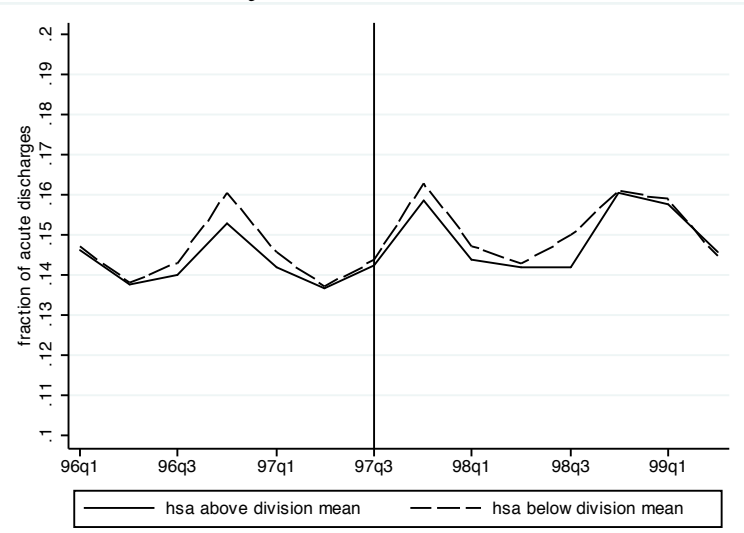

Note: Solid line indicates simulated outcomes in hospital service areas with average home health visits above census division mean, dashed line indicates simulated outcomes in hospital service areas with average home health visits below census division mean. Index patient cohort is $96 \mathrm{q} 1$ acute discharges for IPS, $99 \mathrm{q} 1$ acute discharges for PPS. Vertical line for IPS graphs indicates quarter prior to IPS implementation, for PPS graphs quarter prior to PPS implementation 


\begin{tabular}{|c|c|c|c|}
\hline & $\begin{array}{l}\text { (1) Stroke } \\
90 \text { day episode }\end{array}$ & $\begin{array}{l}\text { (2) Hip fracture, } \\
90 \text { day episode }\end{array}$ & $\begin{array}{l}\text { (3) Joint, } \\
90 \text { day episode }\end{array}$ \\
\hline Age & 77.90 & 82.43 & 73.58 \\
\hline Male & 0.41 & 0.23 & 0.35 \\
\hline White & 0.83 & 0.93 & 0.91 \\
\hline MSA & 0.71 & 0.71 & 0.69 \\
\hline MSA adjacent & 0.16 & 0.16 & 0.17 \\
\hline non-MSA & 0.13 & 0.13 & 0.14 \\
\hline $\begin{array}{l}\text { Comorbid } \\
\text { conditions(any) }\end{array}$ & 0.72 & 0.78 & 0.54 \\
\hline $\begin{array}{l}\text { Comorbid } \\
\text { conditions(n) }\end{array}$ & 1.26 & 1.49 & 0.82 \\
\hline $\begin{array}{l}\text { Complications } \\
\text { (any) }\end{array}$ & 0.25 & 0.57 & 0.41 \\
\hline Any home health & 0.36 & 0.45 & 0.61 \\
\hline $\begin{array}{l}\text { Home health } \\
\text { payments } \\
\text { (conditional on } \\
\text { use) }\end{array}$ & 2705.70 & 2491.52 & 1887.53 \\
\hline $\begin{array}{l}\text { Home health } \\
\text { costs } \\
\text { (conditional on } \\
\text { use) }\end{array}$ & 2764.26 & 2404.48 & 1698.74 \\
\hline Any re-admission & 0.27 & 0.24 & 0.13 \\
\hline $\mathrm{N}$ & $1,738,220$ & $1,311,755$ & $1,671,211$ \\
\hline
\end{tabular}

Notes: Sample includes 90-day episodes following acute discharges for each primary diagnosis occurring from January 1996 through June 2002. Measures calculated from Medicare claims and denominator files. 


\begin{tabular}{|c|c|c|c|c|c|c|}
\hline \multirow[b]{3}{*}{ Mean } & \multirow{2}{*}{\multicolumn{2}{|c|}{$\begin{array}{l}\text { (1) } \\
\text { Medicare home health payments } \\
\text { IPS }\end{array}$}} & \multicolumn{2}{|c|}{$\begin{array}{c}(2) \\
\text { Home health costs }\end{array}$} & \multicolumn{2}{|c|}{$\begin{array}{c}(3) \\
\text { Home health admission }\end{array}$} \\
\hline & & & IPS & PPS & IPS & PPS \\
\hline & 2592 & 2737 & 2860 & 2572 & 0.386 & 0.332 \\
\hline POST1 & $\begin{array}{l}-179.08 * * * \\
(4.58)\end{array}$ & $\begin{array}{l}688.59 * * * \\
(13.21)\end{array}$ & $\begin{array}{l}-132.32 * * * \\
(3.03)\end{array}$ & $\begin{array}{l}-3.69 \\
(5.43)\end{array}$ & $\begin{array}{l}-0.024^{* * *} \\
(0.000)\end{array}$ & $\begin{array}{l}-0.031^{* * *} \\
(0.000)\end{array}$ \\
\hline POST2 & $\begin{array}{l}-391.78 * * * \\
(7.29)\end{array}$ & $\begin{array}{l}703.45^{* * *} \\
(10.61)\end{array}$ & $\begin{array}{l}-254.53 * * * \\
(5.06)\end{array}$ & $\begin{array}{l}116.98 * * * \\
(3.79)\end{array}$ & $\begin{array}{l}-0.062 * * * \\
(0.000)\end{array}$ & $\begin{array}{l}-0.018 * * * \\
(0.001)\end{array}$ \\
\hline POST3 & $\begin{array}{l}-576.50 * * * \\
(10.94)\end{array}$ & $\begin{array}{l}674.11 * * * \\
(11.22)\end{array}$ & $\begin{array}{l}-487.57 * * * \\
(10.22)\end{array}$ & $\begin{array}{l}45.72 * * * \\
(3.87)\end{array}$ & $\begin{array}{l}-0.052 * * * \\
(0.001)\end{array}$ & $\begin{array}{l}-0.029 * * * \\
(0.001)\end{array}$ \\
\hline POST4 & $\begin{array}{l}-700.22 * * * \\
(13.69)\end{array}$ & $\begin{array}{l}753.09 * * * \\
(10.68)\end{array}$ & $\begin{array}{l}-617.37 * * * \\
(11.63)\end{array}$ & $\begin{array}{l}99.65 * * * \\
(3.67)\end{array}$ & $\begin{array}{l}-0.059 * * * \\
(0.001)\end{array}$ & $\begin{array}{l}-0.029 * * * \\
(0.000)\end{array}$ \\
\hline POST5 & $\begin{array}{l}-746.19 * * * \\
(16.53)\end{array}$ & $\begin{array}{l}810.03 * * * \\
(12.35)\end{array}$ & $\begin{array}{l}-622.26 * * * \\
(15.02)\end{array}$ & $\begin{array}{l}184.09 * * * \\
(5.86)\end{array}$ & $\begin{array}{l}-0.058^{* * *} \\
(0.001)\end{array}$ & $\begin{array}{l}-0.019^{* * *} \\
(0.001)\end{array}$ \\
\hline POST6 & $\begin{array}{l}-713.63 * * * \\
(15.13)\end{array}$ & $\begin{array}{l}759.71 * * * \\
(10.70)\end{array}$ & $\begin{array}{l}-561.68 * * * \\
(13.48)\end{array}$ & $\begin{array}{l}263.13 * * * \\
(3.96)\end{array}$ & $\begin{array}{l}-0.059 * * * \\
(0.001)\end{array}$ & $\begin{array}{l}-0.015^{* * *} \\
(0.001)\end{array}$ \\
\hline POST7 & $\begin{array}{l}-696.43 * * * \\
(15.63)\end{array}$ & $\begin{array}{l}694.22 * * * \\
(10.58)\end{array}$ & $\begin{array}{l}-592.43 * * * \\
(15.00)\end{array}$ & $\begin{array}{l}228.15^{* * * *} \\
(4.72)\end{array}$ & $\begin{array}{l}-0.063 * * * \\
(0.001)\end{array}$ & $\begin{array}{l}-0.018^{* * *} \\
(0.001)\end{array}$ \\
\hline Time trend & $\begin{array}{l}0.81 \\
(1.05)\end{array}$ & $\begin{array}{l}37.46^{* * *} \\
(0.44)\end{array}$ & $\begin{array}{l}6.15^{* * *} \\
(0.68)\end{array}$ & $\begin{array}{l}-10.62 * * * \\
(0.62)\end{array}$ & $\begin{array}{l}-0.001 * * * \\
(0.000)\end{array}$ & $\begin{array}{l}-0.001 * * * \\
(0.000)\end{array}$ \\
\hline $\begin{array}{l}\text { Observations } \\
\text { R-squared }\end{array}$ & $\begin{array}{l}441,952 \\
0.32\end{array}$ & $\begin{array}{l}327,264 \\
0.72\end{array}$ & $\begin{array}{l}441,952 \\
0.21\end{array}$ & $\begin{array}{l}327,264 \\
0.04\end{array}$ & $\begin{array}{l}1,049,510 \\
0.18\end{array}$ & $\begin{array}{l}933,688 \\
0.05\end{array}$ \\
\hline
\end{tabular}

Notes: *** indicates significant at 1 percent level, $* * 5$ percent, $* 10$ percent. Estimates from regression of simulated payments, costs, or admissions on POST1-POST7 and quarterly trend. Index cohort is 96q1 patients for IPS, 99q1 patients for PPS. Standard errors clustered on health referral region are presented in parentheses. 


\begin{tabular}{|c|c|c|c|c|c|c|}
\hline \multirow[b]{3}{*}{ Mean } & \multirow{2}{*}{\multicolumn{2}{|c|}{$\begin{array}{l}\text { Medicare home health payments } \\
\text { IPS }\end{array}$}} & \multicolumn{2}{|c|}{$\begin{array}{c}\text { (2) } \\
\text { Home health costs }\end{array}$} & \multicolumn{2}{|c|}{$\begin{array}{c}\text { (3) } \\
\text { Home health admission }\end{array}$} \\
\hline & & & IPS & PPS & IPS & PPS \\
\hline & 2255 & 2633 & 2479 & 2272 & 0.461 & 0.434 \\
\hline POST1 & $\begin{array}{l}-142.42 * * * \\
(2.32)\end{array}$ & $\begin{array}{l}898.95^{* * *} \\
(9.78)\end{array}$ & $\begin{array}{l}-88.71^{* * *} \\
(2.29)\end{array}$ & $\begin{array}{l}50.48 * * * \\
(3.56)\end{array}$ & $\begin{array}{l}-0.026^{* * *} \\
(0.000)\end{array}$ & $\begin{array}{l}-0.032 * * * \\
(0.000)\end{array}$ \\
\hline POST2 & $\begin{array}{l}-269.28 * * * \\
(3.58)\end{array}$ & $\begin{array}{l}929.24 * * * \\
(6.39)\end{array}$ & $\begin{array}{l}-151.68 * * * \\
(2.60)\end{array}$ & $\begin{array}{l}137.81 * * * \\
(4.03)\end{array}$ & $\begin{array}{l}-0.077 * * * \\
(0.000)\end{array}$ & $\begin{array}{l}-0.024 * * * \\
(0.000)\end{array}$ \\
\hline POST3 & $\begin{array}{l}-396.29 * * * \\
(8.34)\end{array}$ & $\begin{array}{l}867.07 * * * \\
(4.47)\end{array}$ & $\begin{array}{l}-309.10^{* * *} \\
(7.36)\end{array}$ & $\begin{array}{l}87.19 * * * \\
(4.15)\end{array}$ & $\begin{array}{l}-0.051 * * * \\
(0.001)\end{array}$ & $\begin{array}{l}-0.030^{* * *} \\
(0.000)\end{array}$ \\
\hline POST4 & $\begin{array}{l}-549.50 * * * \\
(7.42)\end{array}$ & $\begin{array}{l}924.67 * * * \\
(3.86)\end{array}$ & $\begin{array}{l}-477.24 * * * \\
(6.80)\end{array}$ & $\begin{array}{l}107.45^{* * *} \\
(4.78)\end{array}$ & $\begin{array}{l}-0.061 * * * \\
(0.001)\end{array}$ & $\begin{array}{l}-0.036^{* * *} \\
(0.000)\end{array}$ \\
\hline POST5 & $\begin{array}{l}-563.53 * * * \\
(7.80)\end{array}$ & $\begin{array}{l}978.09 * * * \\
(4.24)\end{array}$ & $\begin{array}{l}-452.24 * * * \\
(6.78)\end{array}$ & $\begin{array}{l}235.23^{* * *} \\
(5.51)\end{array}$ & $\begin{array}{l}-0.057^{* * *} \\
(0.001)\end{array}$ & $\begin{array}{l}-0.031 * * * \\
(0.000)\end{array}$ \\
\hline POST6 & $\begin{array}{l}-522.61 * * * \\
(9.25)\end{array}$ & $\begin{array}{l}882.60 * * * \\
(5.15)\end{array}$ & $\begin{array}{l}-391.34 * * * \\
(8.07)\end{array}$ & $\begin{array}{l}279.56^{* * * *} \\
(6.34)\end{array}$ & $\begin{array}{l}-0.051^{* * *} \\
(0.001)\end{array}$ & $\begin{array}{l}-0.039^{* * *} \\
(0.001)\end{array}$ \\
\hline POST7 & $\begin{array}{l}-526.46^{* * *} \\
(7.68)\end{array}$ & $\begin{array}{l}787.49 * * * \\
(3.93)\end{array}$ & $\begin{array}{l}-434.20 * * * \\
(6.47)\end{array}$ & $\begin{array}{l}228.13^{* * *} \\
(6.00)\end{array}$ & $\begin{array}{l}-0.048^{* * *} \\
(0.001)\end{array}$ & $\begin{array}{l}-0.036 * * * \\
(0.001)\end{array}$ \\
\hline time trend & $\begin{array}{l}-8.61 * * * \\
(0.92)\end{array}$ & $\begin{array}{l}56.82 * * * \\
(0.66)\end{array}$ & $\begin{array}{l}-3.61 * * * \\
(0.63)\end{array}$ & $\begin{array}{l}-6.31 * * * \\
(0.73)\end{array}$ & $\begin{array}{l}0.001 * * * \\
(0.000)\end{array}$ & $\begin{array}{l}0.004 * * * \\
(0.000)\end{array}$ \\
\hline $\begin{array}{l}\text { Observations } \\
\text { R-squared }\end{array}$ & $\begin{array}{l}366,002 \\
0.28\end{array}$ & $\begin{array}{l}300,734 \\
0.78\end{array}$ & $\begin{array}{l}366,002 \\
0.18\end{array}$ & $\begin{array}{l}300,734 \\
0.07\end{array}$ & $\begin{array}{l}751,604 \\
0.028\end{array}$ & $\begin{array}{l}705,376 \\
0.003\end{array}$ \\
\hline
\end{tabular}

Notes: $* * *$ indicates significant at 1 percent level, $* * 5$ percent, $* 10$ percent. Estimates from regression of simulated payments, costs, or admissions on POST1-POST7 and quarterly trend. Index cohort is 96q1 patients for IPS, 99q1 patients for PPS. Standard errors clustered on health referral region are presented in parentheses. 


\begin{tabular}{|c|c|c|c|c|c|c|}
\hline \multirow[b]{3}{*}{ Mean } & \multirow{2}{*}{\multicolumn{2}{|c|}{$\begin{array}{l}\text { Medicare home health payments } \\
\text { IPS }\end{array}$}} & \multicolumn{2}{|c|}{$\begin{array}{c}\text { (2) } \\
\text { Home health costs }\end{array}$} & \multicolumn{2}{|c|}{$\begin{array}{c}(3) \\
\text { Home health admission }\end{array}$} \\
\hline & & & IPS & PPS & IPS & PPS \\
\hline & 1551 & 2069 & 1688 & 1656 & 0.636 & 0.582 \\
\hline POST1 & $\begin{array}{l}-47.38^{* * *} \\
(2.65)\end{array}$ & $\begin{array}{l}1,016.08^{* * *} \\
(6.04)\end{array}$ & $\begin{array}{l}-36.14^{* * *} \\
(2.13)\end{array}$ & $\begin{array}{l}\text { 64.80*** } \\
(1.97)\end{array}$ & $\begin{array}{l}-0.016^{* * *} \\
(0.000)\end{array}$ & $\begin{array}{l}-0.026^{* * *} \\
(0.000)\end{array}$ \\
\hline POST2 & $\begin{array}{l}-163.50 * * * \\
(3.33)\end{array}$ & $\begin{array}{l}1,042.06^{* * *} \\
(3.79)\end{array}$ & $\begin{array}{l}-69.85^{* * *} \\
(2.74)\end{array}$ & $\begin{array}{l}185.61^{* * *} \\
(1.68)\end{array}$ & $\begin{array}{l}-0.048^{* * *} \\
(0.001)\end{array}$ & $\begin{array}{l}-0.009 * * * \\
(0.000)\end{array}$ \\
\hline POST3 & $\begin{array}{l}-211.77 * * * \\
(3.92)\end{array}$ & $\begin{array}{l}1,050.30 * * * \\
(4.13)\end{array}$ & $\begin{array}{l}-131.52 * * * \\
(3.58)\end{array}$ & $\begin{array}{l}160.54 * * * \\
(1.73)\end{array}$ & $\begin{array}{l}-0.052 * * * \\
(0.001)\end{array}$ & $\begin{array}{l}-0.023 * * * \\
(0.001)\end{array}$ \\
\hline POST4 & $\begin{array}{l}-264.42 * * * \\
(4.62)\end{array}$ & $\begin{array}{l}1,076.90 * * * \\
(3.77)\end{array}$ & $\begin{array}{l}-189.89 * * * \\
(4.26)\end{array}$ & $\begin{array}{l}164.15^{* * *} \\
(1.91)\end{array}$ & $\begin{array}{l}-0.066^{* * *} \\
(0.001)\end{array}$ & $\begin{array}{l}-0.022 * * * \\
(0.001)\end{array}$ \\
\hline POST5 & $\begin{array}{l}-297.88^{* * *} \\
(5.24)\end{array}$ & $\begin{array}{l}1,156.45^{* * *} \\
(5.04)\end{array}$ & $\begin{array}{l}-212.65 * * * \\
(4.87)\end{array}$ & $\begin{array}{l}206.62^{* * * *} \\
(2.18)\end{array}$ & $\begin{array}{l}-0.071 * * * \\
(0.001)\end{array}$ & $\begin{array}{l}-0.010^{* * *} \\
(0.001)\end{array}$ \\
\hline POST6 & $\begin{array}{l}-275.80 * * * \\
(6.37)\end{array}$ & $\begin{array}{l}1,122.03 * * * \\
(3.37)\end{array}$ & $\begin{array}{l}-157.24 * * * \\
(6.25)\end{array}$ & $\begin{array}{l}258.25^{* * *} \\
(2.52)\end{array}$ & $\begin{array}{l}-0.057 * * * \\
(0.001)\end{array}$ & $\begin{array}{l}0.001 \\
(0.001)\end{array}$ \\
\hline POST7 & $\begin{array}{l}-288.08 * * * \\
(6.90)\end{array}$ & $\begin{array}{l}1,067.57 * * * \\
(3.65)\end{array}$ & $\begin{array}{l}-200.14 * * * \\
(6.87)\end{array}$ & $\begin{array}{l}250.43 * * * \\
(2.48)\end{array}$ & $\begin{array}{l}-0.071 * * * \\
(0.001)\end{array}$ & $\begin{array}{l}-0.005^{* * *} \\
(0.001)\end{array}$ \\
\hline time trend & $\begin{array}{l}-7.14 * * * \\
(0.23)\end{array}$ & $\begin{array}{l}38.86^{* * *} \\
(0.19)\end{array}$ & $\begin{array}{l}-2.80 * * * \\
(0.27)\end{array}$ & $\begin{array}{l}0.80^{* * *} \\
(0.26)\end{array}$ & $\begin{array}{l}0.001 * * * \\
(0.000)\end{array}$ & $\begin{array}{l}-0.002 * * * \\
(0.000)\end{array}$ \\
\hline $\begin{array}{l}\text { Observations } \\
\text { R-squared }\end{array}$ & $\begin{array}{l}550,438 \\
0.13\end{array}$ & $\begin{array}{l}534,128 \\
0.82\end{array}$ & $\begin{array}{l}550,438 \\
0.05\end{array}$ & $\begin{array}{l}534,128 \\
0.12\end{array}$ & $\begin{array}{l}834,091 \\
0.091\end{array}$ & $\begin{array}{l}878,528 \\
0.027\end{array}$ \\
\hline
\end{tabular}

Notes: $* * *$ indicates significant at 1 percent level, $* * 5$ percent, $* 10$ percent. Estimates from a regression of simulated payments, costs, or admissions on POST1-POST7 and quarterly trend. Index cohort is 96q1 patients for IPS, 99q1 patients for PPS. Standard errors clustered on health referral region are presented in parentheses. 


\begin{tabular}{|c|c|c|c|c|c|c|}
\hline \multirow[b]{3}{*}{ Mean } & \multicolumn{2}{|c|}{$\begin{array}{c}\text { (1) } \\
\text { Medicare home health payments }\end{array}$} & \multicolumn{2}{|c|}{$\begin{array}{c}(2) \\
\text { Home health costs }\end{array}$} & \multicolumn{2}{|c|}{$\begin{array}{c}(3) \\
\text { Home health admission }\end{array}$} \\
\hline & II & PPS & & PPS & IPS & PPS \\
\hline & 2179 & 3310 & 2531 & 2661 & 0.344 & 0.321 \\
\hline POST1 & $\begin{array}{l}-0.65 \\
(2.72)\end{array}$ & $\begin{array}{l}-4.19 \\
(2.72)\end{array}$ & $\begin{array}{l}-0.73 \\
(2.77)\end{array}$ & $\begin{array}{l}-1.93 \\
(2.40)\end{array}$ & $\begin{array}{l}-0.000 \\
(0.000)\end{array}$ & $\begin{array}{l}-0.001 * \\
(0.000)\end{array}$ \\
\hline POST2 & $\begin{array}{l}-0.72 \\
(3.57)\end{array}$ & $\begin{array}{l}1.96 \\
(4.05)\end{array}$ & $\begin{array}{l}0.19 \\
(3.65)\end{array}$ & $\begin{array}{l}4.33 \\
(3.36)\end{array}$ & $\begin{array}{l}-0.001^{*} \\
(0.000)\end{array}$ & $\begin{array}{l}-0.001 * * \\
(0.000)\end{array}$ \\
\hline POST3 & $\begin{array}{l}-1.87 \\
(2.96)\end{array}$ & $\begin{array}{l}-0.16 \\
(4.57)\end{array}$ & $\begin{array}{l}-2.15 \\
(3.01)\end{array}$ & $\begin{array}{l}1.25 \\
(3.85)\end{array}$ & $\begin{array}{l}-0.001^{*} \\
(0.000)\end{array}$ & $\begin{array}{l}-0.001 * \\
(0.000)\end{array}$ \\
\hline POST4 & $\begin{array}{l}-0.99 \\
(3.61)\end{array}$ & $\begin{array}{l}4.53 \\
(5.01)\end{array}$ & $\begin{array}{l}-3.31 \\
(3.74)\end{array}$ & $\begin{array}{l}6.53^{*} \\
(3.92)\end{array}$ & $\begin{array}{l}-0.002 * * * \\
(0.001)\end{array}$ & $\begin{array}{l}-0.001 * * \\
(0.001)\end{array}$ \\
\hline POST5 & $\begin{array}{l}-4.78 \\
(4.12)\end{array}$ & $\begin{array}{l}5.88 \\
(5.83)\end{array}$ & $\begin{array}{l}-6.48 \\
(4.18)\end{array}$ & $\begin{array}{l}6.22 \\
(4.99)\end{array}$ & $\begin{array}{l}-0.001 * * \\
(0.001)\end{array}$ & $\begin{array}{l}-0.001 * * \\
(0.001)\end{array}$ \\
\hline POST6 & $\begin{array}{l}-0.69 \\
(4.49)\end{array}$ & $\begin{array}{l}17.59 * * * \\
(6.22)\end{array}$ & $\begin{array}{l}-3.26 \\
(4.45)\end{array}$ & $\begin{array}{l}11.97^{* *} \\
(5.01)\end{array}$ & $\begin{array}{l}-0.002 * * * \\
(0.001)\end{array}$ & $\begin{array}{l}-0.001 \\
(0.001)\end{array}$ \\
\hline POST7 & $\begin{array}{l}-1.29 \\
(4.89)\end{array}$ & $\begin{array}{l}17.88^{* *} \\
(7.15)\end{array}$ & $\begin{array}{l}-4.55 \\
(4.90)\end{array}$ & $\begin{array}{l}14.34 * * \\
(5.63)\end{array}$ & $\begin{array}{l}-0.002 * * * \\
(0.001)\end{array}$ & $\begin{array}{l}-0.000 \\
(0.001)\end{array}$ \\
\hline time trend & $\begin{array}{l}-0.08 \\
(0.40)\end{array}$ & $\begin{array}{l}-0.51 \\
(0.72)\end{array}$ & $\begin{array}{l}0.08 \\
(0.41)\end{array}$ & $\begin{array}{l}-0.38 \\
(0.54)\end{array}$ & $\begin{array}{l}0.000 * * * \\
(0.000)\end{array}$ & $\begin{array}{l}0.000 * * * \\
(0.000)\end{array}$ \\
\hline $\begin{array}{l}\text { Observations } \\
\text { R-squared }\end{array}$ & $\begin{array}{l}376,426 \\
0.00\end{array}$ & $\begin{array}{l}300,446 \\
0.00\end{array}$ & $\begin{array}{l}376,426 \\
0.00\end{array}$ & $\begin{array}{l}300,446 \\
0.00\end{array}$ & $\begin{array}{l}967,550 \\
0.000\end{array}$ & $\begin{array}{l}900,877 \\
0.000\end{array}$ \\
\hline
\end{tabular}

Notes: *** indicates significant at 1 percent level, ** 5 percent, $* 10$ percent. Estimates from regression of simulated payments, costs, or admissions on POST1-POST7 and quarterly trend. Treatment and admission functions for each patient cohort are estimated using 99q2 patients for IPS, and 02q2 patients for PPS. Standard errors clustered on health referral region are presented in parentheses. 


\begin{tabular}{|c|c|c|c|c|c|c|}
\hline & \multicolumn{2}{|c|}{$\begin{array}{c}(1) \\
\text { Medicare home health payments }\end{array}$} & \multicolumn{2}{|c|}{$\begin{array}{c}(2) \\
\text { Home health costs }\end{array}$} & \multicolumn{2}{|c|}{$\begin{array}{c}(3) \\
\text { Home health admission }\end{array}$} \\
\hline & IPS & PPS & IPS & PPS & IPS & PPS \\
\hline Mean & 2255 & 3343 & 2479 & 2377 & 0.438 & 0.441 \\
\hline POST1 & $\begin{array}{l}-3.98 \\
(2.69)\end{array}$ & $\begin{array}{l}-5.52 * * \\
(2.52)\end{array}$ & $\begin{array}{l}-6.20^{* *} \\
(2.86)\end{array}$ & $\begin{array}{l}-9.70^{* * *} \\
(2.25)\end{array}$ & $\begin{array}{l}0.009 * * * \\
(0.001)\end{array}$ & $\begin{array}{l}0.007 * * * \\
(0.001)\end{array}$ \\
\hline POST2 & $\begin{array}{l}-2.62 \\
(3.10)\end{array}$ & $\begin{array}{l}-1.21 \\
(4.09)\end{array}$ & $\begin{array}{l}-2.00 \\
(3.30)\end{array}$ & $\begin{array}{l}-6.37^{*} \\
(3.33)\end{array}$ & $\begin{array}{l}-0.001 \\
(0.001)\end{array}$ & $\begin{array}{l}0.008 * * * \\
(0.001)\end{array}$ \\
\hline POST3 & $\begin{array}{l}2.02 \\
(3.56)\end{array}$ & $\begin{array}{l}3.77 \\
(4.38)\end{array}$ & $\begin{array}{l}2.30 \\
(3.66)\end{array}$ & $\begin{array}{l}-0.78 \\
(3.60)\end{array}$ & $\begin{array}{l}0.002 \\
(0.001)\end{array}$ & $\begin{array}{l}0.006 * * * \\
(0.001)\end{array}$ \\
\hline POST4 & $\begin{array}{l}-6.68 \\
(4.31)\end{array}$ & $\begin{array}{l}1.24 \\
(4.59)\end{array}$ & $\begin{array}{l}-8.11^{*} \\
(4.42)\end{array}$ & $\begin{array}{l}-1.23 \\
(3.85)\end{array}$ & $\begin{array}{l}0.004 * * * \\
(0.001)\end{array}$ & $\begin{array}{l}0.003^{* *} \\
(0.001)\end{array}$ \\
\hline POST5 & $\begin{array}{l}-7.19^{*} \\
(4.21)\end{array}$ & $\begin{array}{l}3.43 \\
(5.22)\end{array}$ & $\begin{array}{l}-10.09 * * \\
(4.48)\end{array}$ & $\begin{array}{l}-1.61 \\
(4.29)\end{array}$ & $\begin{array}{l}0.013 * * * \\
(0.001)\end{array}$ & $\begin{array}{l}0.009 * * * \\
(0.001)\end{array}$ \\
\hline POST6 & $\begin{array}{l}-0.18 \\
(4.91)\end{array}$ & $\begin{array}{l}18.87 * * * \\
(7.11)\end{array}$ & $\begin{array}{l}-2.41 \\
(5.13)\end{array}$ & $\begin{array}{l}7.57 \\
(5.63)\end{array}$ & $\begin{array}{l}0.004 * * \\
(0.002)\end{array}$ & $\begin{array}{l}0.007 * * * \\
(0.002)\end{array}$ \\
\hline POST7 & $\begin{array}{l}-1.33 \\
(5.69)\end{array}$ & $\begin{array}{l}19.30^{* * * *} \\
(7.23)\end{array}$ & $\begin{array}{l}-3.54 \\
(5.84)\end{array}$ & $\begin{array}{l}9.50 \\
(5.88)\end{array}$ & $\begin{array}{l}0.005^{* * *} \\
(0.002)\end{array}$ & $\begin{array}{l}0.007 * * * \\
(0.002)\end{array}$ \\
\hline time trend & $\begin{array}{l}0.50 \\
(0.46)\end{array}$ & $\begin{array}{l}-0.06 \\
(0.70)\end{array}$ & $\begin{array}{l}0.89^{*} \\
(0.50)\end{array}$ & $\begin{array}{l}0.54 \\
(0.54)\end{array}$ & $\begin{array}{l}-0.001^{* * *} \\
(0.000)\end{array}$ & $\begin{array}{l}-0.000 \\
(0.000)\end{array}$ \\
\hline $\begin{array}{l}\text { Observations } \\
\text { R-squared }\end{array}$ & $\begin{array}{l}326,489 \\
0.00\end{array}$ & $\begin{array}{l}303,891 \\
0.00\end{array}$ & $\begin{array}{l}326,489 \\
0.00\end{array}$ & $\begin{array}{l}303,891 \\
0.00\end{array}$ & $\begin{array}{l}716,300 \\
0.001\end{array}$ & $\begin{array}{l}695,149 \\
0.000\end{array}$ \\
\hline
\end{tabular}

Notes: *** indicates significant at 1 percent level, $* * 5$ percent, $* 10$ percent. Estimates from regression of simulated payments, costs, or admissions on POST1-POST7 and quarterly trend. Treatment and admission functions for each patient cohort are estimated using 99q2 patients for IPS, and 02q2 patients for PPS. Standard errors clustered on health referral region are presented in parentheses. 


\begin{tabular}{|c|c|c|c|c|c|c|}
\hline & \multicolumn{2}{|c|}{ Medicare home health payments } & \multicolumn{2}{|c|}{$\begin{array}{c}(2) \\
\text { Home health costs }\end{array}$} & \multicolumn{2}{|c|}{$\begin{array}{c}\text { (3) } \\
\text { Home health admission }\end{array}$} \\
\hline & IPS & PPS & IPS & PPS & IPS & PPS \\
\hline & 1331 & 2858 & 1547 & 1825 & 0.595 & 0.575 \\
\hline POST1 & $\begin{array}{l}-18.56^{* * *} \\
(2.18)\end{array}$ & $\begin{array}{l}-16.94 * * * \\
(2.58)\end{array}$ & $\begin{array}{l}-22.46^{* * *} \\
(2.15)\end{array}$ & $\begin{array}{l}-20.44 * * * \\
(2.21)\end{array}$ & $\begin{array}{l}-0.004 * * * \\
(0.000)\end{array}$ & $\begin{array}{l}-0.006^{* * *} \\
(0.000)\end{array}$ \\
\hline POST2 & $\begin{array}{l}-27.52 * * * \\
(2.72)\end{array}$ & $\begin{array}{l}-25.58 * * * \\
(3.41)\end{array}$ & $\begin{array}{l}-28.92 * * * \\
(2.61)\end{array}$ & $\begin{array}{l}-34.99^{* * * *} \\
(2.51)\end{array}$ & $\begin{array}{l}-0.004 * * * \\
(0.001)\end{array}$ & $\begin{array}{l}-0.008^{* * *} \\
(0.001)\end{array}$ \\
\hline POST3 & $\begin{array}{l}-2.07 \\
(2.73)\end{array}$ & $\begin{array}{l}-0.67 \\
(4.27)\end{array}$ & $\begin{array}{l}-2.37 \\
(2.58)\end{array}$ & $\begin{array}{l}-9.40 * * * \\
(3.03)\end{array}$ & $\begin{array}{l}0.001 \\
(0.001)\end{array}$ & $\begin{array}{l}-0.002 * * \\
(0.001)\end{array}$ \\
\hline POST4 & $\begin{array}{l}-6.53 * * \\
(3.06)\end{array}$ & $\begin{array}{l}-9.24 * * \\
(4.54)\end{array}$ & $\begin{array}{l}-7.56 * * * \\
(2.89)\end{array}$ & $\begin{array}{l}-15.51 * * * \\
(3.23)\end{array}$ & $\begin{array}{l}0.000 \\
(0.001)\end{array}$ & $\begin{array}{l}-0.004 * * * \\
(0.001)\end{array}$ \\
\hline POST5 & $\begin{array}{l}-25.19 * * * \\
(3.52)\end{array}$ & $\begin{array}{l}-20.31^{* * *} \\
(5.38)\end{array}$ & $\begin{array}{l}-29.49^{* * *} \\
(3.40)\end{array}$ & $\begin{array}{l}-27.33^{* * *} \\
(3.70)\end{array}$ & $\begin{array}{l}-0.005^{* * *} \\
(0.001)\end{array}$ & $\begin{array}{l}-0.008^{* * *} \\
(0.001)\end{array}$ \\
\hline POST6 & $\begin{array}{l}-24.39 * * * \\
(4.29)\end{array}$ & $\begin{array}{l}-17.06^{* * *} \\
(5.61)\end{array}$ & $\begin{array}{l}-28.41 * * * \\
(3.77)\end{array}$ & $\begin{array}{l}-34.50 * * * \\
(4.00)\end{array}$ & $\begin{array}{l}-0.002 * \\
(0.001)\end{array}$ & $\begin{array}{l}-0.009 * * * \\
(0.001)\end{array}$ \\
\hline POST7 & $\begin{array}{l}-10.04^{* * *} \\
(4.58)\end{array}$ & $\begin{array}{l}2.00 \\
(6.44)\end{array}$ & $\begin{array}{l}-14.68 * * * \\
(4.17)\end{array}$ & $\begin{array}{l}-15.33^{* * *} \\
(4.53)\end{array}$ & $\begin{array}{l}0.002 * \\
(0.001)\end{array}$ & $\begin{array}{l}-0.003^{* *} \\
(0.001)\end{array}$ \\
\hline time trend & $\begin{array}{l}1.17^{* * * *} \\
(0.39)\end{array}$ & $\begin{array}{l}1.62 * * * \\
(0.60)\end{array}$ & $\begin{array}{l}1.91 * * * \\
(0.36)\end{array}$ & $\begin{array}{l}2.88 * * * \\
(0.42)\end{array}$ & $\begin{array}{l}-0.000 \\
(0.000)\end{array}$ & $\begin{array}{l}0.001 * * * \\
(0.000)\end{array}$ \\
\hline $\begin{array}{l}\text { Observations } \\
\text { R-squared }\end{array}$ & $\begin{array}{l}543,082 \\
0.00\end{array}$ & $\begin{array}{l}548,893 \\
0.00\end{array}$ & $\begin{array}{l}543,082 \\
0.00\end{array}$ & $\begin{array}{l}548,893 \\
0.00\end{array}$ & $\begin{array}{l}853,478 \\
0.001\end{array}$ & $\begin{array}{l}940,014 \\
0.001\end{array}$ \\
\hline
\end{tabular}

Notes: *** indicates significant at 1 percent level, $* * 5$ percent, $* 10$ percent. Estimates from regression of simulated payments, costs, or admissions on POST1-POST7 and quarterly trend. Treatment and admission functions for each patient cohort are estimated using 99q2 patients for IPS, and 02q2 patients for PPS. Standard errors clustered on health referral region are presented in parentheses. 


\begin{tabular}{|c|c|c|c|c|c|c|}
\hline \multirow[b]{3}{*}{ Mean } & \multicolumn{2}{|c|}{$\begin{array}{c}\text { (1) } \\
\text { Medicare home health payments }\end{array}$} & \multicolumn{2}{|c|}{$\begin{array}{c}(2) \\
\text { Home health costs }\end{array}$} & \multicolumn{2}{|c|}{$\begin{array}{c}(3) \\
\text { Home health admission }\end{array}$} \\
\hline & IPS & PPS & IPS & PPS & IPS & PPS \\
\hline & 1733 & 3103 & 2011 & 2188 & 0.455 & 0.448 \\
\hline POST1 & $\begin{array}{l}-6.60^{* * *} \\
(2.13)\end{array}$ & $\begin{array}{l}-7.82 * * * \\
(1.93)\end{array}$ & $\begin{array}{l}-8.11 * * * \\
(2.38)\end{array}$ & $\begin{array}{l}-11.53^{* * *} \\
(2.10)\end{array}$ & $\begin{array}{l}-0.001^{* *} \\
(0.000)\end{array}$ & $\begin{array}{l}-0.001 * * * \\
(0.000)\end{array}$ \\
\hline POST2 & $\begin{array}{l}-22.61^{* * *} \\
(2.86)\end{array}$ & $\begin{array}{l}-17.36^{* * *} \\
(3.16)\end{array}$ & $\begin{array}{l}-23.85^{* * *} \\
(3.12)\end{array}$ & $\begin{array}{l}-26.21^{* * *} \\
(3.09)\end{array}$ & $\begin{array}{l}-0.003^{* * *} \\
(0.001)\end{array}$ & $\begin{array}{l}0.002 * * * \\
(0.001)\end{array}$ \\
\hline POST3 & $\begin{array}{l}-2.40 \\
(3.05)\end{array}$ & $\begin{array}{l}-8.83^{* *} \\
(3.80)\end{array}$ & $\begin{array}{l}-2.58 \\
(3.26)\end{array}$ & $\begin{array}{l}-19.29^{* * *} \\
(3.37)\end{array}$ & $\begin{array}{l}-0.002 * * * \\
(0.001)\end{array}$ & $\begin{array}{l}0.004 * * * \\
(0.001)\end{array}$ \\
\hline POST4 & $\begin{array}{l}-1.64 \\
(3.02)\end{array}$ & $\begin{array}{l}-15.59^{* * *} \\
(3.96)\end{array}$ & $\begin{array}{l}-2.53 \\
(3.28)\end{array}$ & $\begin{array}{l}-26.44^{* * *} \\
(3.55)\end{array}$ & $\begin{array}{l}-0.003^{* * *} \\
(0.001)\end{array}$ & $\begin{array}{l}0.004 * * * \\
(0.001)\end{array}$ \\
\hline POST5 & $\begin{array}{l}-8.34 * * \\
(3.46)\end{array}$ & $\begin{array}{l}-14.82^{* * *} \\
(4.57)\end{array}$ & $\begin{array}{l}-10.29 * * * \\
(3.80)\end{array}$ & $\begin{array}{l}-25.60 * * * \\
(3.81)\end{array}$ & $\begin{array}{l}-0.001 \\
(0.001)\end{array}$ & $\begin{array}{l}0.004 * * * \\
(0.001)\end{array}$ \\
\hline POST6 & $\begin{array}{l}-11.90^{* * *} \\
(4.38)\end{array}$ & $\begin{array}{l}-13.59^{* *} \\
(5.56)\end{array}$ & $\begin{array}{l}-14.28^{* * *} \\
(4.63)\end{array}$ & $\begin{array}{l}-32.56^{* * *} \\
(4.76)\end{array}$ & $\begin{array}{l}-0.003^{* * *} \\
(0.001)\end{array}$ & $\begin{array}{l}0.006^{* * * *} \\
(0.001)\end{array}$ \\
\hline POST7 & $\begin{array}{l}0.48 \\
(4.60)\end{array}$ & $\begin{array}{l}-3.50 \\
(5.79)\end{array}$ & $\begin{array}{l}-1.34 \\
(4.82)\end{array}$ & $\begin{array}{l}-22.95^{* * *} \\
(4.73)\end{array}$ & $\begin{array}{l}-0.003^{* * *} \\
(0.001)\end{array}$ & $\begin{array}{l}0.007 * * * \\
(0.001)\end{array}$ \\
\hline time trend & $\begin{array}{l}-2.61 * * * \\
(0.39)\end{array}$ & $\begin{array}{l}-0.58 \\
(0.58)\end{array}$ & $\begin{array}{l}-2.51 * * * \\
(0.42)\end{array}$ & $\begin{array}{l}-0.59 \\
(0.45)\end{array}$ & $\begin{array}{l}0.000 * * * \\
(0.000)\end{array}$ & $\begin{array}{l}0.001^{* * *} \\
(0.000)\end{array}$ \\
\hline $\begin{array}{l}\text { Observations } \\
\text { R-squared }\end{array}$ & $\begin{array}{l}1,245,997 \\
0.00\end{array}$ & $\begin{array}{l}1,153,230 \\
0.00\end{array}$ & $\begin{array}{l}1,245,997 \\
0.00\end{array}$ & $\begin{array}{l}1,153,230 \\
0.00\end{array}$ & $\begin{array}{l}2,537,328 \\
0.000\end{array}$ & $\begin{array}{l}2,536,040 \\
0.002\end{array}$ \\
\hline
\end{tabular}

Notes: $* * *$ indicates significant at 1 percent level, $* * 5$ percent, $* 10$ percent. Estimates from regression of simulated payments, costs, or admissions on POST1-POST7 and quarterly trend. Treatment and admission functions (controlling for main effects of each tracer condition) for each patient cohort are estimated using 99q2 patients for IPS, and 02q2 patients for PPS. Standard errors clustered on health referral region are presented in parentheses. 


\begin{tabular}{|c|c|c|c|c|c|c|}
\hline & \multicolumn{3}{|c|}{ Mortality (90-days post-acute discharge) } & \multicolumn{3}{|c|}{ Acute readmissions } \\
\hline & (1) & (2) & (3) & (4) & (5) & $(6)$ \\
\hline & Stroke & Hip & Joint & Stroke & Hip & Joint \\
\hline Mean & 0.147 & 0.111 & 0.008 & 0.271 & 0.227 & 0.121 \\
\hline POST x Q1 & $\begin{array}{l}0.002 * * * \\
(0.000)\end{array}$ & $\begin{array}{l}0.003 * * * \\
(0.001)\end{array}$ & $\begin{array}{l}-0.000^{* * *} \\
(0.000)\end{array}$ & $\begin{array}{l}0.001 * * * \\
(0.000)\end{array}$ & $\begin{array}{l}0.007 * * * \\
(0.000)\end{array}$ & $\begin{array}{l}0.001 * * * \\
(0.000)\end{array}$ \\
\hline POST x Q2 & $\begin{array}{l}0.002 * * * \\
(0.000)\end{array}$ & $\begin{array}{l}-0.003^{* * *} \\
(0.000)\end{array}$ & $\begin{array}{l}0.000 * * * \\
(0.000)\end{array}$ & $\begin{array}{l}-0.000 \\
(0.000)\end{array}$ & $\begin{array}{l}0.005 * * * \\
(0.000)\end{array}$ & $\begin{array}{l}0.001 * * * \\
(0.000)\end{array}$ \\
\hline POST x Q3 & $\begin{array}{l}-0.000 \\
(0.000)\end{array}$ & $\begin{array}{l}-0.000 \\
(0.001)\end{array}$ & $\begin{array}{l}-0.000^{* * *} \\
(0.000)\end{array}$ & $\begin{array}{l}0.002 * * * \\
(0.000)\end{array}$ & $\begin{array}{l}-0.004^{* * *} \\
(0.000)\end{array}$ & $\begin{array}{l}0.006 * * * \\
(0.000)\end{array}$ \\
\hline POST x Q4 & $\begin{array}{l}0.002 * * * \\
(0.000)\end{array}$ & $\begin{array}{l}-0.004^{* * *} \\
(0.000)\end{array}$ & $\begin{array}{l}0.001 * * * \\
(0.000)\end{array}$ & $\begin{array}{l}-0.002 * * * \\
(0.000)\end{array}$ & $\begin{array}{l}-0.001^{* * *} \\
(0.000)\end{array}$ & $\begin{array}{l}0.001 * * * \\
(0.000)\end{array}$ \\
\hline Q1 & $\begin{array}{l}-0.010^{* * *} \\
(0.000)\end{array}$ & $\begin{array}{l}-0.014 * * * \\
(0.000)\end{array}$ & $\begin{array}{l}0.001 * * * \\
(0.000)\end{array}$ & $\begin{array}{l}-0.003 * * * \\
(0.000)\end{array}$ & $\begin{array}{l}-0.004 * * * \\
(0.000)\end{array}$ & $\begin{array}{l}0.000 \\
(0.000)\end{array}$ \\
\hline Q2 & $\begin{array}{l}-0.018^{* * *} \\
(0.000)\end{array}$ & $\begin{array}{l}-0.024 * * * \\
(0.000)\end{array}$ & $\begin{array}{l}-0.001^{* * *} \\
(0.000)\end{array}$ & $\begin{array}{l}-0.011 * * * \\
(0.000)\end{array}$ & $\begin{array}{l}-0.014 * * * \\
(0.000)\end{array}$ & $\begin{array}{l}0.001 * * * \\
(0.000)\end{array}$ \\
\hline Q3 & $\begin{array}{l}-0.014^{* * *} \\
(0.000)\end{array}$ & $\begin{array}{l}-0.021^{* * *} \\
(0.000)\end{array}$ & $\begin{array}{l}0.000 * * \\
(0.000)\end{array}$ & $\begin{array}{l}-0.009^{* * *} \\
(0.000)\end{array}$ & $\begin{array}{l}-0.008^{* * * *} \\
(0.000)\end{array}$ & $\begin{array}{l}-0.000 \\
(0.000)\end{array}$ \\
\hline Linear time trend & $\begin{array}{l}0.001 * * * \\
(0.000)\end{array}$ & $\begin{array}{l}0.001 * * * \\
(0.000)\end{array}$ & $\begin{array}{l}0.000 * * * \\
(0.000)\end{array}$ & $\begin{array}{l}0.001 * * * \\
(0.000)\end{array}$ & $\begin{array}{l}0.001 * * * \\
(0.000)\end{array}$ & $\begin{array}{l}-0.000 \\
(0.000)\end{array}$ \\
\hline $\begin{array}{l}\text { Observations } \\
\text { R-squared }\end{array}$ & $\begin{array}{l}1,049,510 \\
0.005\end{array}$ & $\begin{array}{l}751,604 \\
0.013\end{array}$ & $\begin{array}{l}834,092 \\
0.002\end{array}$ & $\begin{array}{l}1,049,510 \\
0.008\end{array}$ & $\begin{array}{l}751,604 \\
0.016\end{array}$ & $\begin{array}{l}834,092 \\
0.001\end{array}$ \\
\hline
\end{tabular}

Notes: $* * *$ indicates significant at 1 percent level, $* * 5$ percent, $* 10$ percent. Estimates come from regression of outcomes on quarter indicators, and interaction of POST with quarter indicators. Index cohort is 1996 q1 discharges. Standard errors clustered on health referral region are presented in parentheses. 


\begin{tabular}{|c|c|c|c|c|c|c|}
\hline & \multicolumn{3}{|c|}{ Mortality (90-days post-acute discharge) } & \multicolumn{3}{|c|}{ Acute readmissions } \\
\hline & $\begin{array}{c}(1) \\
\text { Stroke }\end{array}$ & $\begin{array}{l}\text { (2) } \\
\text { Hip }\end{array}$ & $\begin{array}{c}(3) \\
\text { Joint }\end{array}$ & $\begin{array}{c}(4) \\
\text { Stroke }\end{array}$ & $\begin{array}{l}\text { (5) } \\
\text { Hip }\end{array}$ & $\begin{array}{l}(6) \\
\text { Joint }\end{array}$ \\
\hline Mean & 0.160 & 0.127 & 0.008 & 0.276 & 0.246 & 0.126 \\
\hline POST x Q1 & $\begin{array}{l}0.007 * * * \\
(0.000)\end{array}$ & $\begin{array}{l}0.007 * * * \\
(0.000)\end{array}$ & $\begin{array}{l}0.001 * * * \\
(0.000)\end{array}$ & $\begin{array}{l}0.000 \\
(0.000)\end{array}$ & $\begin{array}{l}0.008^{* * *} \\
(0.001)\end{array}$ & $\begin{array}{l}-0.000 \\
(0.000)\end{array}$ \\
\hline POST x Q2 & $\begin{array}{l}0.006^{* * * *} \\
(0.000)\end{array}$ & $\begin{array}{l}0.007 * * * \\
(0.000)\end{array}$ & $\begin{array}{l}0.001 * * * \\
(0.000)\end{array}$ & $\begin{array}{l}-0.001 * * * \\
(0.000)\end{array}$ & $\begin{array}{l}0.005 * * * \\
(0.001)\end{array}$ & $\begin{array}{l}0.001 * * * \\
(0.000)\end{array}$ \\
\hline POST x Q3 & $\begin{array}{l}0.003 * * * \\
(0.000)\end{array}$ & $\begin{array}{l}0.003 * * * \\
(0.000)\end{array}$ & $\begin{array}{l}0.001 * * * \\
(0.000)\end{array}$ & $\begin{array}{l}-0.003^{* * *} \\
(0.000)\end{array}$ & $\begin{array}{l}0.002 * * * \\
(0.000)\end{array}$ & $\begin{array}{l}0.001 \\
(0.000)\end{array}$ \\
\hline POST x Q4 & $\begin{array}{l}-0.003 * * * \\
(0.000)\end{array}$ & $\begin{array}{l}-0.007 * * * \\
(0.000)\end{array}$ & $\begin{array}{l}-0.000 \\
(0.000)\end{array}$ & $\begin{array}{l}-0.005^{* * *} \\
(0.000)\end{array}$ & $\begin{array}{l}-0.002 * * * \\
(0.000)\end{array}$ & $\begin{array}{l}-0.003 * * * \\
(0.000)\end{array}$ \\
\hline Q1 & $\begin{array}{l}-0.008 * * * \\
(0.000)\end{array}$ & $\begin{array}{l}-0.013 * * * \\
(0.000)\end{array}$ & $\begin{array}{l}-0.001 * * * \\
(0.000)\end{array}$ & $\begin{array}{l}-0.006^{* * *} \\
(0.000)\end{array}$ & $\begin{array}{l}-0.007 * * * \\
(0.000)\end{array}$ & $\begin{array}{l}-0.003 * * * \\
(0.000)\end{array}$ \\
\hline Q2 & $\begin{array}{l}-0.020 * * * \\
(0.000)\end{array}$ & $\begin{array}{l}-0.026^{* * *} \\
(0.000)\end{array}$ & $\begin{array}{l}-0.002 * * * \\
(0.000)\end{array}$ & $\begin{array}{l}-0.012 * * * \\
(0.000)\end{array}$ & $\begin{array}{l}-0.017 * * * \\
(0.000)\end{array}$ & $\begin{array}{l}-0.006^{* * *} \\
(0.000)\end{array}$ \\
\hline Q3 & $\begin{array}{l}-0.015^{* * *} \\
(0.000)\end{array}$ & $\begin{array}{l}-0.022 * * * \\
(0.000)\end{array}$ & $\begin{array}{l}-0.002 * * * \\
(0.000)\end{array}$ & $\begin{array}{l}-0.006^{* * *} \\
(0.000)\end{array}$ & $\begin{array}{l}-0.014 * * * \\
(0.000)\end{array}$ & $\begin{array}{l}-0.002 * * * \\
(0.000)\end{array}$ \\
\hline Linear time trend & $\begin{array}{l}0.000 * * * \\
(0.000)\end{array}$ & $\begin{array}{l}0.001 * * * \\
(0.000)\end{array}$ & $\begin{array}{l}-0.000 * * * \\
(0.000)\end{array}$ & $\begin{array}{l}0.001 * * * \\
(0.000)\end{array}$ & $\begin{array}{l}0.001 * * * \\
(0.000)\end{array}$ & $\begin{array}{l}0.000 * * * \\
(0.000)\end{array}$ \\
\hline $\begin{array}{l}\text { Observations } \\
\text { R-squared }\end{array}$ & $\begin{array}{l}933,688 \\
0.004\end{array}$ & $\begin{array}{l}705,376 \\
0.010\end{array}$ & $\begin{array}{l}878,528 \\
0.002\end{array}$ & $\begin{array}{l}933,688 \\
0.005\end{array}$ & $\begin{array}{l}705,376 \\
0.014\end{array}$ & $\begin{array}{l}878,528 \\
0.002\end{array}$ \\
\hline
\end{tabular}

Notes: *** indicates significant at 1 percent level, $* * 5$ percent, $* 10$ percent. Estimates come from regression of outcomes on quarter indicators, and interaction of POST with quarter indicators. Index cohort is 1999q1 acute discharges. Standard errors clustered on health referral region are presented in parentheses. 


\begin{tabular}{|c|c|c|c|c|c|}
\hline & $\begin{array}{l}(1) \\
\text { Payments }\end{array}$ & $\begin{array}{l}\text { (2) } \\
\text { Costs }\end{array}$ & $\begin{array}{l}(3) \\
\text { Admission }\end{array}$ & $\begin{array}{l}(4) \\
\text { Readmissions }\end{array}$ & $\begin{array}{l}\text { (5) } \\
\text { Mortality }\end{array}$ \\
\hline Mean & 2592 & 2859 & 0.386 & 0.269 & 0.147 \\
\hline $\begin{array}{l}\text { Above } x \\
\text { POST1 }\end{array}$ & $\begin{array}{l}-50.29 * * * \\
(8.15)\end{array}$ & $\begin{array}{l}-22.86 * * \\
(10.00)\end{array}$ & $\begin{array}{l}0.00 * * * \\
(0.00)\end{array}$ & $\begin{array}{l}0.002 * * * \\
(0.000)\end{array}$ & $\begin{array}{l}-0.002 * * * \\
(0.000)\end{array}$ \\
\hline $\begin{array}{l}\text { Above } x \\
\text { POST2 }\end{array}$ & $\begin{array}{l}-77.62^{* * *} \\
(8.55)\end{array}$ & $\begin{array}{l}-38.54 * * * \\
(10.15)\end{array}$ & $\begin{array}{l}-0.00 * * * \\
(0.00)\end{array}$ & $\begin{array}{l}-0.003 * * * \\
(0.001)\end{array}$ & $\begin{array}{l}-0.001 * * \\
(0.000)\end{array}$ \\
\hline $\begin{array}{l}\text { Above } x \\
\text { POST3 }\end{array}$ & $\begin{array}{l}-51.83 * * * \\
(12.12)\end{array}$ & $\begin{array}{l}-39.85 * * * \\
(12.96)\end{array}$ & $\begin{array}{l}-0.00 * * * \\
(0.00)\end{array}$ & $\begin{array}{l}-0.000 \\
(0.001)\end{array}$ & $\begin{array}{l}0.002 * * * \\
(0.000)\end{array}$ \\
\hline $\begin{array}{l}\text { Above x } \\
\text { POST4 }\end{array}$ & $\begin{array}{l}-79.96 * * * \\
(11.47)\end{array}$ & $\begin{array}{l}-54.52 * * * \\
(12.25)\end{array}$ & $\begin{array}{l}0.00 * * * \\
(0.00)\end{array}$ & $\begin{array}{l}0.004 * * * \\
(0.001)\end{array}$ & $\begin{array}{l}-0.005 * * * \\
(0.000)\end{array}$ \\
\hline $\begin{array}{l}\text { Above x } \\
\text { POST5 }\end{array}$ & $\begin{array}{l}-61.70 * * * \\
(14.83)\end{array}$ & $\begin{array}{l}-60.74 * * * \\
(17.47)\end{array}$ & $\begin{array}{l}-0.00 \\
(0.00)\end{array}$ & $\begin{array}{l}-0.004 * * * \\
(0.001)\end{array}$ & $\begin{array}{l}0.002 * * * \\
(0.000)\end{array}$ \\
\hline $\begin{array}{l}\text { Above x } \\
\text { POST6 }\end{array}$ & $\begin{array}{l}-123.25^{* * *} \\
(13.89)\end{array}$ & $\begin{array}{l}-127.07 * * * \\
(13.67)\end{array}$ & $\begin{array}{l}-0.01 * * * \\
(0.00)\end{array}$ & $\begin{array}{l}-0.005 * * * \\
(0.001)\end{array}$ & $\begin{array}{l}0.001 * * * \\
(0.000)\end{array}$ \\
\hline $\begin{array}{l}\text { Above x } \\
\text { POST7 }\end{array}$ & $\begin{array}{l}-32.62 * * \\
(14.05)\end{array}$ & $\begin{array}{l}-66.82 * * * \\
(16.09)\end{array}$ & $\begin{array}{l}-0.00 * * \\
(0.00)\end{array}$ & $\begin{array}{l}0.003 * * * \\
(0.000)\end{array}$ & $\begin{array}{l}0.004 * * * \\
(0.000)\end{array}$ \\
\hline Above & $\begin{array}{l}214.99 * * * \\
(29.33)\end{array}$ & $\begin{array}{l}188.73 * * * \\
(31.11)\end{array}$ & $\begin{array}{l}0.01 * * \\
(0.00)\end{array}$ & $\begin{array}{l}-0.001 \\
(0.002)\end{array}$ & $\begin{array}{l}-0.003 * * \\
(0.001)\end{array}$ \\
\hline $\begin{array}{l}\mathrm{N} \\
\mathrm{R} 2\end{array}$ & $\begin{array}{l}403,718 \\
0.33\end{array}$ & $\begin{array}{l}403,634 \\
0.22\end{array}$ & $\begin{array}{l}961,598 \\
0.18\end{array}$ & $\begin{array}{l}961,618 \\
0.008\end{array}$ & $\begin{array}{l}961,338 \\
0.006\end{array}$ \\
\hline
\end{tabular}

Notes: *** indicates significant at 1 percent level, ** 5 percent, * 10 percent. Estimates of regression of simulated payments, costs, and admissions on indicators for POST1 through POST7 interacted with "above" division mean indicator and quarter fixed effects. Index cohort is 96q1 acute discharges. Standard errors clustered on health referral region are presented in parentheses. 
Table 7a. Home Health IPS: Changes in probability of home health use and costs as a function of changes in simulated conditional payments

\begin{tabular}{|c|c|c|c|}
\hline & Stroke & Hip & Joint \\
\hline \multicolumn{4}{|c|}{ 1. Predicted change in probability of home health use } \\
\hline Mean & -0.08 & -0.04 & -0.07 \\
\hline$\Delta$ (simulated payments $)$ & $\begin{array}{l}0.00 \\
(0.00)\end{array}$ & $\begin{array}{l}-0.00 * * * \\
(0.00)\end{array}$ & $\begin{array}{l}0.00 * * * \\
(0.00)\end{array}$ \\
\hline Average effect & -0.003 & 0.009 & -0.035 \\
\hline \multicolumn{4}{|c|}{ 2. Predicted change in conditional home health costs } \\
\hline Mean & -521.17 & -512.57 & -225.63 \\
\hline$\Delta$ (simulated payments $)$ & $\begin{array}{l}1.05 * * * \\
(0.01)\end{array}$ & $\begin{array}{l}1.08 * * * \\
(0.01)\end{array}$ & $\begin{array}{l}0.96 * * * \\
(0.01)\end{array}$ \\
\hline \multicolumn{4}{|c|}{ 3. Predicted change in unconditional home health costs } \\
\hline Mean & -424.44 & -330.52 & -263.30 \\
\hline$\Delta($ simulated payments $)$ & $\begin{array}{l}0.53 * * * \\
(0.01)\end{array}$ & $\begin{array}{l}0.44 * * * \\
(0.01)\end{array}$ & $\begin{array}{l}0.92 * * * \\
(0.01)\end{array}$ \\
\hline $\mathrm{N}$ & 74,965 & 53,686 & 62,752 \\
\hline
\end{tabular}

Notes: *** indicates significant at 1 percent level, $* * 5$ percent, $* 10$ percent. Standard errors clustered on health referral region. Regressions of changes in simulated admissions and costs between $1^{\text {st }}$ and $14^{\text {th }}$ quarter on changes in simulated payments for index cohort consisting of patients discharged from acute care in $1996 \mathrm{q} 1$. 


\begin{tabular}{|c|c|c|c|}
\hline & Stroke & Hip & Joint \\
\hline \multicolumn{4}{|c|}{ 1. Predicted change in probability of home health use } \\
\hline Mean & -0.03 & 0.01 & -0.04 \\
\hline$\Delta$ (simulated payments) & $\begin{array}{l}-0.00 * * * \\
(0.00)\end{array}$ & $\begin{array}{l}0.00 \\
(0.00)\end{array}$ & $\begin{array}{l}-0.00 * * * \\
(0.00)\end{array}$ \\
\hline Average effect & -0.017 & 0.002 & -0.017 \\
\hline \multicolumn{4}{|c|}{ 2. Predicted change in conditional home health costs } \\
\hline Mean & 97.22 & 126.46 & 223.62 \\
\hline$\Delta($ simulated payments $)$ & $\begin{array}{l}0.77 * * * \\
(0.02)\end{array}$ & $\begin{array}{l}0.48 * * * \\
(0.01)\end{array}$ & $\begin{array}{l}0.24 * * * \\
(0.01)\end{array}$ \\
\hline \multicolumn{4}{|c|}{ 3. Predicted change in unconditional home health costs } \\
\hline Mean & -47.22 & 82.60 & 71.42 \\
\hline$\Delta($ simulated payments $)$ & $\begin{array}{l}0.23 * * * \\
(0.01)\end{array}$ & $\begin{array}{l}0.24 * * * \\
(0.01)\end{array}$ & $\begin{array}{l}0.16 * * * \\
(0.01)\end{array}$ \\
\hline $\mathrm{N}$ & 66,692 & 50,384 & 62,752 \\
\hline
\end{tabular}

Notes: *** indicates significant at 1 percent level, ** 5 percent, $* 10$ percent. Standard errors clustered on health referral region. Regressions of changes in simulated admissions and costs between $1^{\text {st }}$ and $14^{\text {th }}$ quarter on changes in simulated payments for index cohort consisting of patients discharged from acute care in 1999 q1. 


\section{Appendix Figure 1. Comorbidities and complications for home health patients}

a. Total number of comorbidities

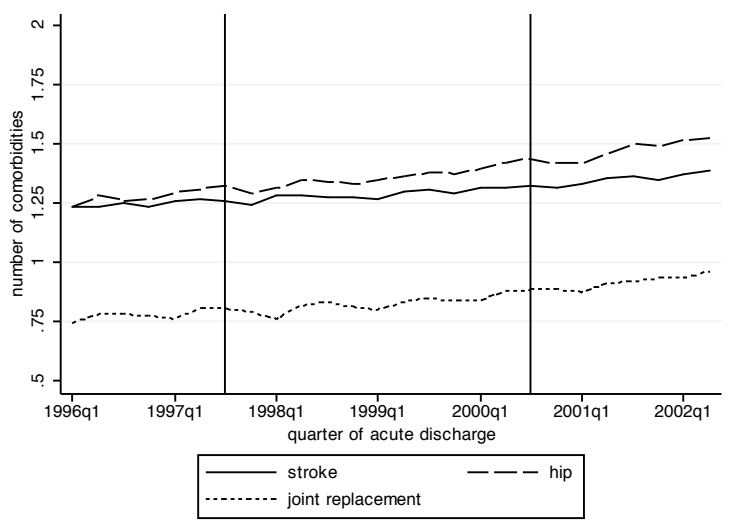

c. Fraction with three or more comorbidities

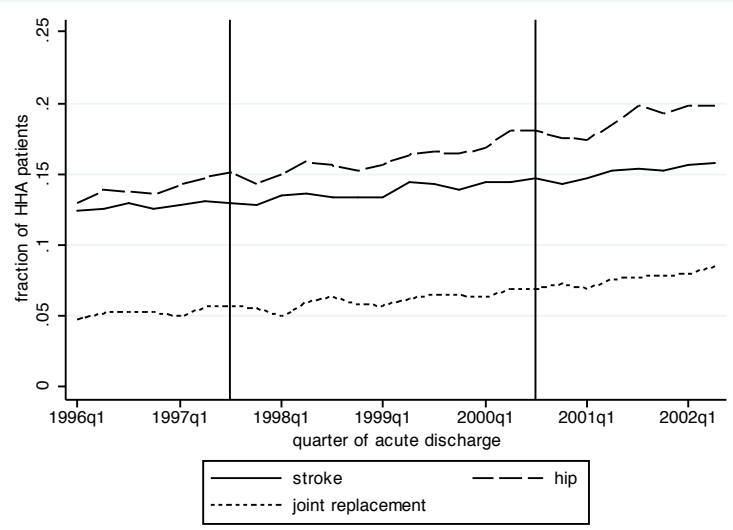

b. Total number of complications

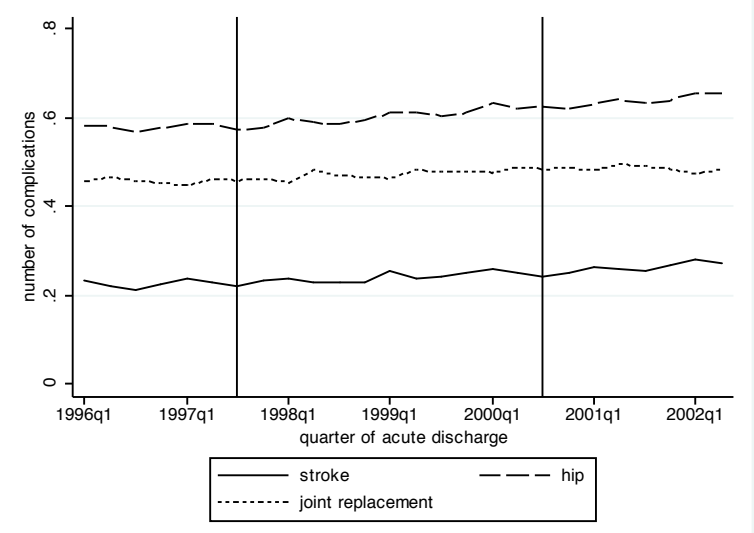

d. Fraction with no comorbidities

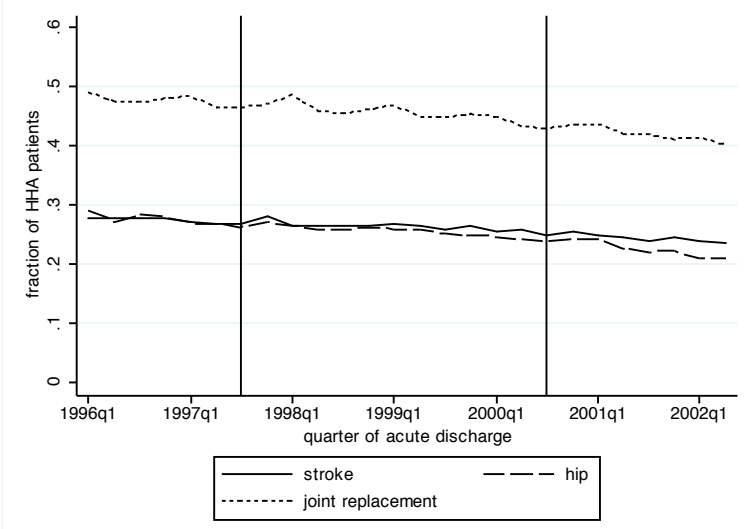


e. Fraction two or more complications

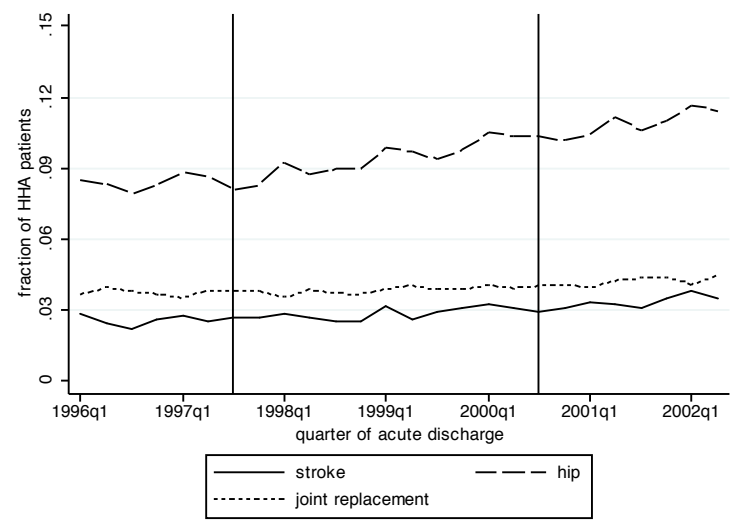

f. Fraction with zero complications

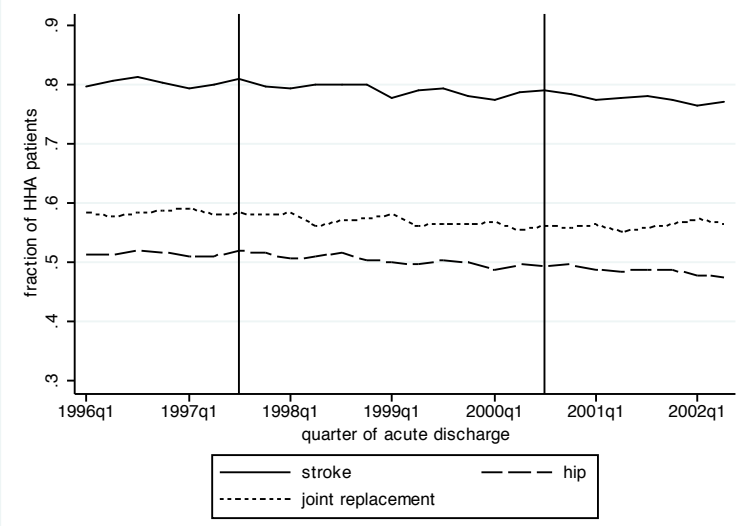

Note: Measures calculated from 100\% Medicare Home Health claims data. Lines indicate average number of comorbidities and complications for patients in home health with an acute discharge for stroke (solid line), hip fracture (dashed line), and lower extremity joint replacement (dotted line). Vertical line in IPS graphs indicates quarter prior to Interim Payment System implementation, for PPS graphs quarter prior to Prospective Payment System implementation. 


\section{Appendix Figure 2. Relative share of each tracer condition in home health patients within sample period}

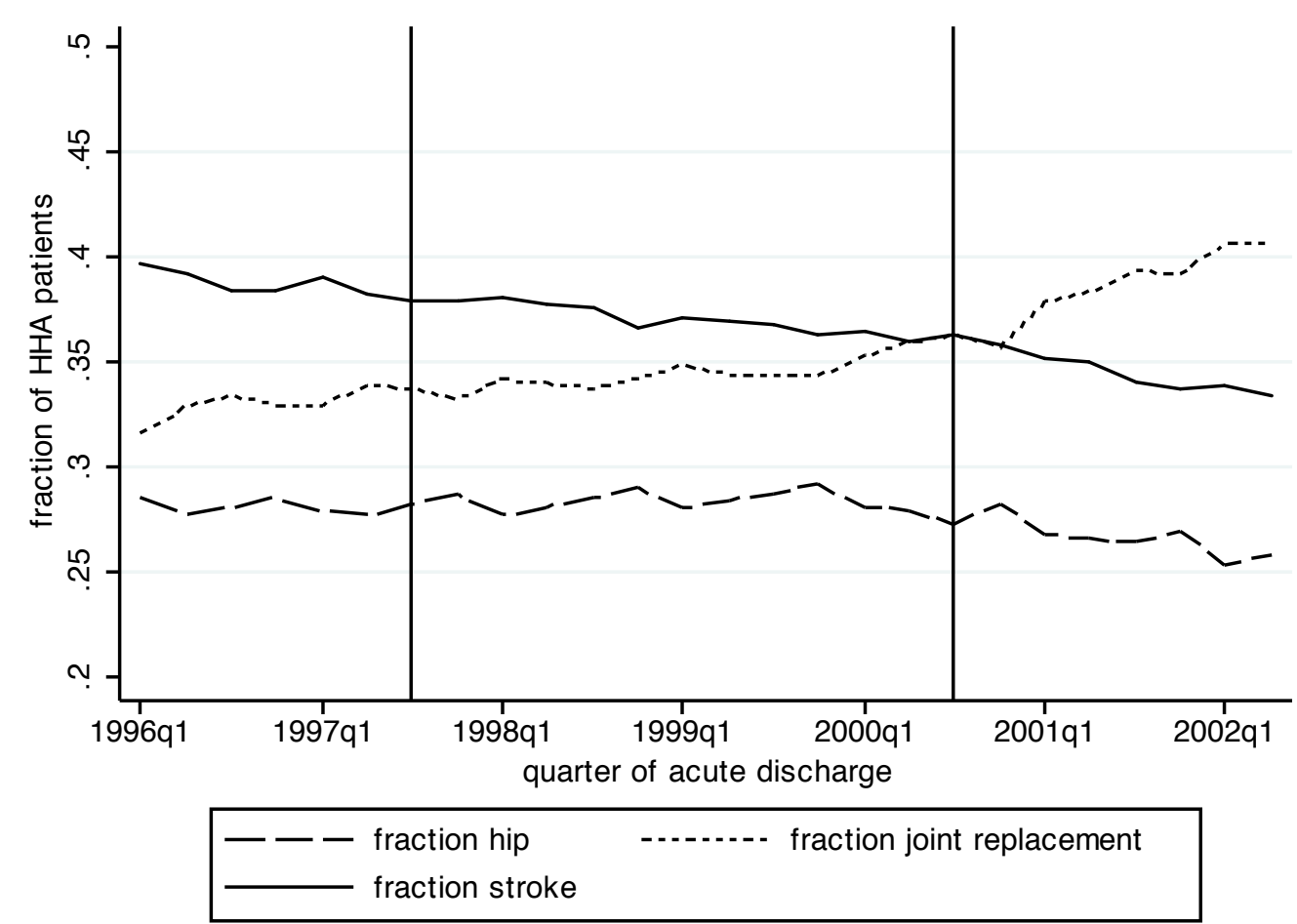

Notes: Figure exhibits the fraction of home health admissions for each tracer condition as a fraction of total hip fracture, stroke, and lower extremity joint replacement admissions in each quarter. The first vertical line indicates the quarter prior to the Interim Payment System (October 1997) and the second vertical line indicates the quarter prior to the Prospective Payment System (October 2000). 


\begin{tabular}{|c|c|c|c|c|c|}
\hline \multicolumn{6}{|c|}{$\begin{array}{l}\text { Appendix Table 1a. Difference-in-difference estimates for IPS, health service } \\
\text { areas above and below division mean number of visits, hip fracture patients }\end{array}$} \\
\hline & $\begin{array}{l}1) \\
\text { Payments }\end{array}$ & $\begin{array}{l}(2) \\
\text { Costs }\end{array}$ & $\begin{array}{l}\text { (3) } \\
\text { Admission }\end{array}$ & $\begin{array}{l}(4) \\
\text { Readmissions }\end{array}$ & $\begin{array}{l}\text { Mortality } \\
\text { Molu }\end{array}$ \\
\hline Mean & 2255 & 2480 & 0.461 & 0.225 & 0.111 \\
\hline $\begin{array}{l}\text { Above } x \\
\text { POST1 }\end{array}$ & $\begin{array}{l}-66.46^{* * *} \\
(6.52)\end{array}$ & $\begin{array}{l}-55.55^{* * *} \\
(9.15)\end{array}$ & $\begin{array}{l}-0.00^{*} \\
(0.00)\end{array}$ & $\begin{array}{l}0.004 * * * \\
(0.001)\end{array}$ & $\begin{array}{l}0.002 * * * \\
(0.000)\end{array}$ \\
\hline $\begin{array}{l}\text { Above } x \\
\text { POST2 }\end{array}$ & $\begin{array}{l}-100.87 * * * \\
(7.25)\end{array}$ & $\begin{array}{l}-80.88^{* * *} \\
(10.06)\end{array}$ & $\begin{array}{l}0.01 * * * \\
(0.00)\end{array}$ & $\begin{array}{l}0.000 \\
(0.000)\end{array}$ & $\begin{array}{l}-0.003^{* * *} \\
(0.001)\end{array}$ \\
\hline $\begin{array}{l}\text { Above x } \\
\text { POST3 }\end{array}$ & $\begin{array}{l}-103.24 * * * \\
(8.42)\end{array}$ & $\begin{array}{l}-99.06^{* * *} \\
(10.72)\end{array}$ & $\begin{array}{l}-0.00 * * * \\
(0.00)\end{array}$ & $\begin{array}{l}-0.002 * * * \\
(0.001)\end{array}$ & $\begin{array}{l}-0.003^{* * *} \\
(0.000)\end{array}$ \\
\hline $\begin{array}{l}\text { Above x } \\
\text { POST4 }\end{array}$ & $\begin{array}{l}-116.99 * * * \\
(12.11)\end{array}$ & $\begin{array}{l}-114.66^{* * *} \\
(14.98)\end{array}$ & $\begin{array}{l}0.00 \\
(0.00)\end{array}$ & $\begin{array}{l}0.004 * * * \\
(0.000)\end{array}$ & $\begin{array}{l}-0.000 \\
(0.001)\end{array}$ \\
\hline $\begin{array}{l}\text { Above x } \\
\text { POST5 }\end{array}$ & $\begin{array}{l}-98.17^{* * *} \\
(11.69)\end{array}$ & $\begin{array}{l}-82.47^{* * *} \\
(13.02)\end{array}$ & $\begin{array}{l}0.00 * * * \\
(0.00)\end{array}$ & $\begin{array}{l}-0.000 \\
(0.001)\end{array}$ & $\begin{array}{l}-0.000 \\
(0.000)\end{array}$ \\
\hline $\begin{array}{l}\text { Above x } \\
\text { POST6 }\end{array}$ & $\begin{array}{l}-88.89 * * * \\
(12.20)\end{array}$ & $\begin{array}{l}-94.09 * * * \\
(15.60)\end{array}$ & $\begin{array}{l}0.00 \\
(0.00)\end{array}$ & $\begin{array}{l}0.006 * * * \\
(0.001)\end{array}$ & $\begin{array}{l}0.004 * * * \\
(0.000)\end{array}$ \\
\hline $\begin{array}{l}\text { Above x } \\
\text { POST7 }\end{array}$ & $\begin{array}{l}-104.38 * * * \\
(11.50)\end{array}$ & $\begin{array}{l}-140.96^{* * *} \\
(13.58)\end{array}$ & $\begin{array}{l}-0.00 * * \\
(0.00)\end{array}$ & $\begin{array}{l}0.004 * * * \\
(0.001)\end{array}$ & $\begin{array}{l}-0.004^{* * *} \\
(0.000)\end{array}$ \\
\hline Above & $\begin{array}{l}214.14^{* * *} \\
(26.98)\end{array}$ & $\begin{array}{l}196.84 * * * \\
(28.71)\end{array}$ & $\begin{array}{l}0.00 \\
(0.00)\end{array}$ & $\begin{array}{l}-0.002 \\
(0.001)\end{array}$ & $\begin{array}{l}0.002 * * \\
(0.001)\end{array}$ \\
\hline $\begin{array}{l}\mathrm{N} \\
\mathrm{R} 2\end{array}$ & $\begin{array}{l}337,036 \\
0.29\end{array}$ & $\begin{array}{l}336,966 \\
0.18\end{array}$ & $\begin{array}{l}693,979 \\
0.03\end{array}$ & $\begin{array}{l}693,994 \\
0.016\end{array}$ & $\begin{array}{l}693,826 \\
0.013\end{array}$ \\
\hline
\end{tabular}

Notes: *** indicates significant at 1 percent level, $* * 5$ percent, $* 10$ percent. Estimates of regression of simulated payments, costs, and admissions on indicators for POST1 through POST7 interacted with "above" division mean indicator and quarter fixed effects. Index cohort is 96q1 acute discharges. Standard errors clustered on health referral region are presented in parentheses. 


\begin{tabular}{|c|c|c|c|c|c|}
\hline \multicolumn{6}{|c|}{$\begin{array}{l}\text { Appendix Table 1b. Difference-in-difference estimates for IPS, health service } \\
\text { areas above and below division mean number of visits, joint replacement } \\
\text { patients }\end{array}$} \\
\hline & (1) & (2) & (3) & (4) & (5) \\
\hline & Payments & Costs & Admission & Readmissions & Mortality \\
\hline Mean & 1551 & 1687 & 0.637 & 0.120 & 0.008 \\
\hline $\begin{array}{l}\text { Above x } \\
\text { POST1 }\end{array}$ & $\begin{array}{l}-7.87 * * \\
(3.67)\end{array}$ & $\begin{array}{l}4.77 \\
(3.67)\end{array}$ & $\begin{array}{l}-0.00 \\
(0.00)\end{array}$ & $\begin{array}{l}-0.003 * * * \\
(0.000)\end{array}$ & $\begin{array}{l}-0.000^{* * *} \\
(0.000)\end{array}$ \\
\hline $\begin{array}{l}\text { Above x } \\
\text { POST2 }\end{array}$ & $\begin{array}{l}-40.19^{* * * *} \\
(4.92)\end{array}$ & $\begin{array}{l}-40.97 * * * \\
(5.55)\end{array}$ & $\begin{array}{l}-0.00 * \\
(0.00)\end{array}$ & $\begin{array}{l}-0.002 * * * \\
(0.000)\end{array}$ & $\begin{array}{l}0.001 * * * \\
(0.000)\end{array}$ \\
\hline $\begin{array}{l}\text { Above x } \\
\text { POST3 }\end{array}$ & $\begin{array}{l}-43.41 * * * \\
(5.15)\end{array}$ & $\begin{array}{l}-45.82 * * * \\
(5.71)\end{array}$ & $\begin{array}{l}0.00 * * * \\
(0.00)\end{array}$ & $\begin{array}{l}-0.000 \\
(0.000)\end{array}$ & $\begin{array}{l}0.001 * * * \\
(0.000)\end{array}$ \\
\hline $\begin{array}{l}\text { Above x } \\
\text { POST4 }\end{array}$ & $\begin{array}{l}-24.03^{* * *} \\
(5.64)\end{array}$ & $\begin{array}{l}-18.36^{* * *} \\
(5.76)\end{array}$ & $\begin{array}{l}-0.00 \\
(0.00)\end{array}$ & $\begin{array}{l}-0.009^{* * *} \\
(0.000)\end{array}$ & $\begin{array}{l}-0.003^{* * *} \\
(0.000)\end{array}$ \\
\hline $\begin{array}{l}\text { Above x } \\
\text { POST5 }\end{array}$ & $\begin{array}{l}-31.38^{* * *} \\
(6.39)\end{array}$ & $\begin{array}{l}-34.10^{* * *} \\
(6.09)\end{array}$ & $\begin{array}{l}-0.01 * * * \\
(0.00)\end{array}$ & $\begin{array}{l}-0.004 * * * \\
(0.000)\end{array}$ & $\begin{array}{l}-0.000 \\
(0.000)\end{array}$ \\
\hline $\begin{array}{l}\text { Above x } \\
\text { POST6 }\end{array}$ & $\begin{array}{l}-21.97 * * * \\
(7.52)\end{array}$ & $\begin{array}{l}-44.45^{* * *} \\
(8.24)\end{array}$ & $\begin{array}{l}-0.01 * * * \\
(0.00)\end{array}$ & $\begin{array}{l}0.002 * * * \\
(0.000)\end{array}$ & $\begin{array}{l}-0.000^{* * *} \\
(0.000)\end{array}$ \\
\hline $\begin{array}{l}\text { Above x } \\
\text { POST7 }\end{array}$ & $\begin{array}{l}-30.32^{* * *} \\
(7.36)\end{array}$ & $\begin{array}{l}-54.58 * * * \\
(8.07)\end{array}$ & $\begin{array}{l}-0.01 * * * \\
(0.00)\end{array}$ & $\begin{array}{l}0.002 * * * \\
(0.000)\end{array}$ & $\begin{array}{l}-0.000 \\
(0.000)\end{array}$ \\
\hline Above & $\begin{array}{l}96.16^{* * * *} \\
(17.79)\end{array}$ & $\begin{array}{l}81.39 * * * \\
(17.58)\end{array}$ & $\begin{array}{l}0.02 * * * \\
(0.00)\end{array}$ & $\begin{array}{l}0.001 \\
(0.001)\end{array}$ & $\begin{array}{l}0.000 * * * \\
(0.000)\end{array}$ \\
\hline $\begin{array}{l}\mathrm{N} \\
\mathrm{R} 2\end{array}$ & $\begin{array}{l}509,054 \\
0.14\end{array}$ & $\begin{array}{l}508,928 \\
0.06\end{array}$ & $\begin{array}{l}770,935 \\
0.10\end{array}$ & $\begin{array}{l}770,938 \\
0.002\end{array}$ & $\begin{array}{l}770,770 \\
0.003\end{array}$ \\
\hline
\end{tabular}

Notes: $* * *$ indicates significant at 1 percent level, $* * 5$ percent, $* 10$ percent.

Estimates of regression of simulated payments, costs, and admissions on indicators for POST1 through POST7 interacted with "above" division mean indicator and quarter fixed effects. Index cohort is 96q1 acute discharges. Standard errors clustered on health referral region are presented in parentheses. 